\title{
Preliminary Assessment of Geothermal Resource Potential at the UTTR
}

Richard P. Smith

Robert P. Breckenridge

Thomas R. Wood

June 2011

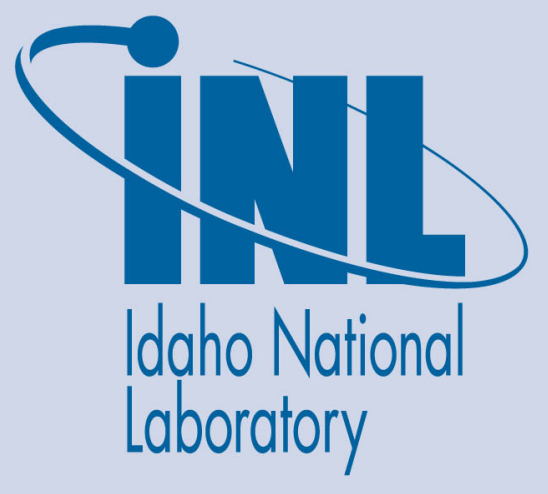

The INL is a U.S. Department of Energy National Laboratory operated by Battelle Energy Alliance 
INL/EXT-11-22215

\title{
Preliminary Assessment of Geothermal Resource Potential at the UTTR
}

\author{
Richard P. Smith \\ Robert P. Breckenridge \\ Thomas R. Wood
}

June 2011

\begin{abstract}
Idaho National Laboratory
Idaho Falls, Idaho 83415
\end{abstract}

http://www.inl.gov

Prepared for the

U.S. Department of Energy

Assistant Secretary for Energy Efficiency and Renewable Energy

Under DOE Idaho Operations Office

Contract DE-AC07-05ID14517 


\section{DISCLAIMER}

This information was prepared as an account of work sponsored by an agency of the U.S. Government. Neither the U.S. Government nor any agency thereof, nor any of their employees, makes any warranty, expressed or implied, or assumes any legal liability or responsibility for the accuracy, completeness, or usefulness, of any information, apparatus, product, or process disclosed, or represents that its use would not infringe privately owned rights. References herein to any specific commercial product, process, or service by trade name, trade mark, manufacturer, or otherwise, does not necessarily constitute or imply its endorsement, recommendation, or favoring by the U.S. Government or any agency thereof. The views and opinions of authors expressed herein do not necessarily state or reflect those of the U.S. Government or any agency thereof. 



\section{EXECUTIVE SUMMARY}

This report describes an in-depth investigation of relevant existing data that may be useful for evaluating the geothermal resource potential of the lands controlled by Hill Air Force Base (HAFB) at the Utah Testing and Training Range (UTTR) and the lands encompassed by the Dugway Proving Grounds (Dugway). Assembled data include published journal articles and maps, as well as extensive collections of geothermal, geologic, geophysical, and geochemical data available from numerous university and government websites. Several geothermal focus areas are identified for future detailed analyses. The review and interpretation of the data presented herein indicates that within the focus areas are prospects that have characteristics similar to other geothermal reservoirs in the Great Basin. Recommendations are provided regarding additional data required to design a well drilling program to more fully characterize the geothermal potential southeast of Wendover, UT, in the western portion of UTTR-S.

The UTTR/Dugway lands are located within the Great Basin of the Basin and Range Province in northwestern Utah, an area of North America known to have thin crust, warm upper mantle rocks, high heat flow, and numerous geothermal systems, which can host geothermal power plants. The UTTR/Dugway area is situated in the Great Salt Lake Desert (GSLD), a structural basin that has been filled with a thick sequence of sediments. This thick sequence of sediments, as well as the waxing and waning of ice age lakes and the more frequent filling and draining of playa lakes, has masked deep subsurface geologic features. Understanding the geothermal regime here is further complicated by the lack of data in the area due to restricted access of large parcels of lands for military reservations. Nevertheless, the limited data from deep wells and the projection of geologic trends into the UTTR/Dugway area indicate a strong possibility that geothermal systems exist here.

Four different geothermal exploration models for basin and range deep-circulation geothermal systems are described in this report. These models are sometimes called conceptual models and define the salient features of the geology, temperature regimes, and hydrogeology that must be present in order for a viable geothermal exploration target to exist. A geothermal system with commercial potential must have a combination of heat, water, and permeability. It is the coincident occurrence of multiple characteristics that contribute to the existence of a geothermal reservoir capable of electrical generation. The geothermal exploration models suggest that the location of the UTTR/Dugway lands within the Great Basin, near deep-seated faults, near regions of high extension rates, and over horst- and graben-bounding faults, makes it a prime exploration area for deep-circulation geothermal resources.

The four exploration models are discussed in relation to a number of characteristics relevant to the discovery of geothermal systems on UTTR/Dugway Lands. The characteristics considered include: (1) the location within the Great Basin; (2) the geologic structure of the basin beneath the GSLD; (3) thermal gradient and heat flow; (4) thickness of basin-fill sediments; (5) resurfacing of basin floor; (6) thermal springs; (7) cold springs; (8) Quaternary faults; (9) contemporary seismicity; (10) source of water for geothermal systems; (11) characteristics of rocks in adjacent and intra-basin mountain ranges; and (12) lack of exploration due to a military presence. Four areas of the UTTR are identified that hold the most promise for the discovery of a geothermal resource. 
Focus Area 1 will be the first area considered for more detailed investigation during the summer and early fall of 2011. In addition to its favorable geologic and geophysical characteristics, Focus Area 1 is also in close proximity to existing power transmission lines, capable of handling power from a geothermal plant. Scientifically, this area is of interest for several reasons. First, the Blue Lakes Springs and other warm springs occur here and maintain a temperature of $84^{\circ} \mathrm{F}$. Second, the Wendover Graben (as identified from existing gravity surveys of the area) probably extends to the southwest from the area east of Wendover into this focus area. The southeastern side of the Wendover Graben has not been mapped into the Blue Lakes area yet, but an extrapolation of the gravity gradient motivates collection of additional gravity data in the area this summer. A complex system of two or more graben intersecting beneath the desert in the area south and southeast of Wendover is thought to exist in Area 1. Such intersections of graben and faults of different trends commonly produce extensive zones of fractured rock, which serve as pathways for the deep circulation of geothermal waters and for the development of near-surface geothermal reservoirs. Third, temperature data from several nearby petroleum exploration and deep brine wells suggest very high thermal gradients exist in the area. And finally, the presence of several earthquake epicenters east of Wendover suggest that the graben-bounding faults are still active, which is a condition favorable for maintaining open pathways for circulation of geothermal waters in the fault zones. Taken as a whole, the existing data are indicative of the conditions necessary for the presence of a significant geothermal resource in Focus Area 1.

Our results indicate that the best use of exploration funds will focus on collecting data to better characterize the nature and extent of the Wendover Graben, searching for other evidence of geologic faulting, better characterization of the permeability of the deeper geologic formations, and collection of geochemistry data from wells and springs in the area to "finger print" waters for evidence of geothermal influences. These planned investigations for the summer and fall of 2011 include a high resolution gravity survey, geochemical sampling of springs and wells, temperature logging of deep wells (as available), evaluation of surface lineaments that might indicate deep structures, and a detailed analysis of available geophysical well logs for oil exploration wells. This data will be used for identifying drilling targets with high potential for a geothermal discovery in Focus Area 1.

It is noted that in the long-term, the other identified focus areas may be just as promising as Focus Area 1 and are worthy of more detailed exploration as well, and should not be neglected. Also, in large parts of UTTR-South and Dugway, so little geophysical and geologic data exist that subsurface interpretations are not possible. A long-term program of data collection in those areas may reveal other promising areas for geothermal exploration.

Please note that the figures displayed in this report are formatted to fit on the page where they are called out. For a larger, clearer, and more readable version of these figures, please use the zoom feature in Word by going the View Tab and selecting Zoom. 


\section{CONTENTS}

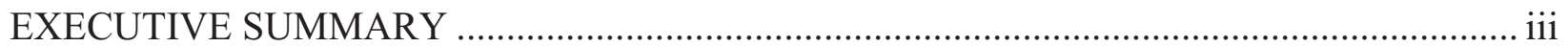

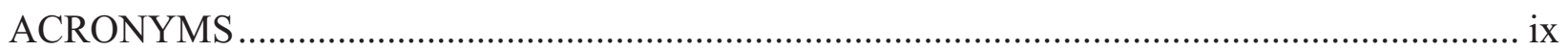

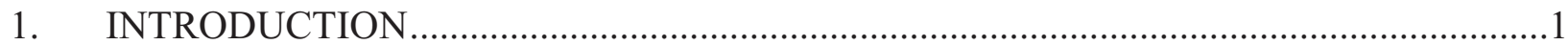

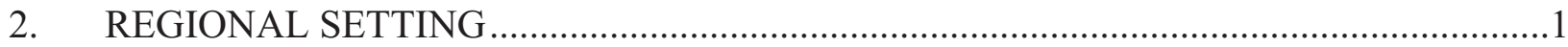

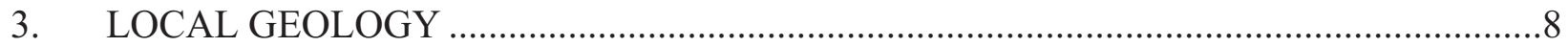

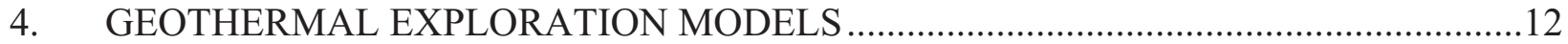

4.1 Characteristics Relevant to Discovery of Geothermal Systems on

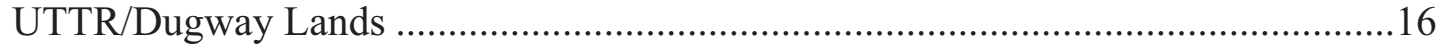

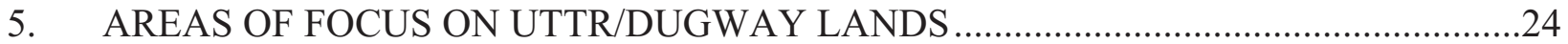

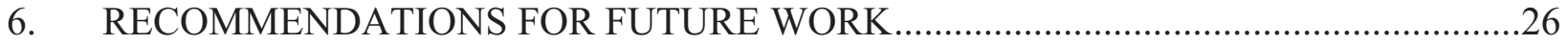

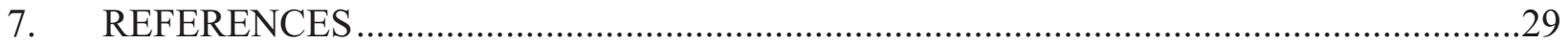




\section{FIGURES}

Figure 1. Map of the Great Basin showing geothermal potential based on a number of geothermal indicators. Geothermal potential indicated by colors with warm colors having higher potential than cool colors. Also identified are several geothermal fields discussed in the text (modified from the Great Basin Geothermal Center's website at: http://www.nbmg.unr.edu/dox/m151/m151plate.pdf).

Figure 2. Map showing the position of the UTTR/Dugway areas within the GSLD. Also shown are locations of thermal springs (color coded for temperature) and wells (color coded for geothermal gradient). Modified from the Utah Geological Survey's website at http://geology.utah.gov/emp/geothermal/pdf/ut_geoth_tg.pdf.....

Figure 3A. Heat flow map of the United States, with the state of Utah and the UTTR area identified. Heat flow is the amount of heat being conducted from depth and escaping from the earth's surface. It is usually given in units of milli-watts per square meter of the earth's surface $\left(\mathrm{mW} / \mathrm{m}^{2}\right)$. Warmer colors represent areas with high heat flow and cool colors represent areas with lower heat flow. The UTTR area is characterized by high heat flow of $90-100 \mathrm{~mW} / \mathrm{m}^{2}$, similar to most of the Basin and Range province. Modified from the Southern Methodist University Geothermal Laboratory website at: http://smu.edu/geothermal/heatflow/geothermal_all_us_clipped_150dpi_pagesize_legend .gif.

Figure 3B. Map of the United States showing favorability for discovery of deep enhanced geothermal systems. An "enhanced" geothermal system is one that possesses temperatures sufficiently high for electrical generation, but may need artificially induced permeability (fracturing) to allow sufficient flow of geothermal fluids to the surface. Favorability is based on a number of criteria, including temperature at a depth of 3 to $10 \mathrm{~km}$. The UTTR area of Utah is among the most favorable in the U.S. Modified from the National Renewable Energy Laboratory website at http://www.nrel.gov/gis/images/geothermal_resource2009-final.jpg.

Figure 4. Cross-section of the Dixie Valley, Nevada, geothermal field with interpreted fluid flow vectors. Based on known geothermal gradients at Dixie Valley, cool water (indicated by blue arrows) migrates to great depths $(\sim 9 \mathrm{~km})$ where it is heated, and returns by flowing up the basin-bounding fault zones (indicated by red arrows). Temperatures of the geothermal fluids exceed $200^{\circ} \mathrm{C}$ in some areas, and a $63 \mathrm{MW}$ primary generation power plant is in operation there. This cross section is drawn perpendicular to the fault zone. Just as important is migration of fluids downward within the fault zone in areas adjacent to the geothermal field and then upward along the fault zone in the area of the geothermal

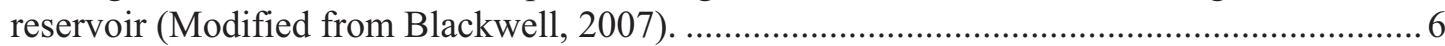

Figure 5. Close-up view of the UTTR/Dugway areas on the map shown in Figure 1........................... 7

Figure 6. Simplified geologic cross-sections of the GSLD: (A) East-West cross-section through Newfoundland Mountains and part of UTTR-N; (B) Northwest-trending cross-section through the Wendover Graben, just north of UTTR-S. Petroleum exploration well SS1 projected into the cross-section from the south. Petroleum exploration well AM1F projected into the cross-section from the north (Modified from Cook et al., 1964). Refer to Figure 8 for locations of these cross sections. 8

Figure 7. Map showing geographic features of the UTTR and GSLD area. UTTR/Dugway areas outlined by green lines. Interstate 80 identified by blue line, and minor roads by solid red lines. Great Salt Lake shaded blue. Towns shaded tan. National Forests shaded green. Quaternary faults indicated by dashed red lines. Thermal springs indicated by red dots. 9 
Figure 8. Map showing important geologic features and data relevant to identification of geothermal exploration areas. The locations of the cross-sections shown in Figure 6 are labeled XC-A and XC-B.

Figure 9. Isostatic gravity map of the UTTR/Dugway area. The contours show lines of equal intensity of gravitational force, and are color coded with higher gravity intensities in yellow, orange, and red colors, while lower intensities are identified in green and blue colors. Note that the denser rocks of the mountain ranges are characterized by high gravity values (i.e., orange and red contours), while the less-dense valley fill material between ranges is characterized by low gravity values (i.e., yellow, green, and blue contours). Gravity data downloaded from the PACES website at the University of Texas at El Paso and contoured by the INL GIS laboratory.

Figure 10. Isostatic gravity map of the UTTR/Dugway area with interpreted graben-bounding faults. Based on experience in many basins and on geophysical theory, faults coincide with the zones of steepest gravity gradient between the ranges and intervening valleys. Faults interpreted by Cook et al.(1964) in dashed black lines. Faults interpreted for this study in pink lines. In both cases, the downthrown side is indicated by the balls attached to the lines. The yellow-shaded area in western UTTR-S is the area of geothermal assessment focus based on proximity to electric infrastructure.

Figure 11. Detailed map of the Wendover Graben area and Focus Area 1. Graben-bounding faults shown by black dashed lines (Cook et al., 1964) and pink solid lines (this study); springs identified by blue dots, earthquake epicenters by green circles, seismic lines by red lines labeled SL1 through SL3, oil wells by heavy black circles, deep brine wells by red dots (DB3 = Deep Brine Well \#3; SS1 = Shell Salduro \#1; AMF1 = Alpha Minerals Federal $\# 1)$.

Figure 12. Seismic Reflection Section 3. Major reflectors are indicated by heavy black bands labeled $\mathrm{A}, \mathrm{B}, \mathrm{C}$, and D. The yellow shaded section above reflector " $\mathrm{A}$ " is interpreted to be unconsolidated sediments 1650 feet thick, The green shaded section between reflector " $\mathrm{A}$ " and " $\mathrm{C}$ " is interpreted to be consolidated Neogene sediments, mostly limestones and interbedded shales about 1450 feet thick. The red shaded section between reflectors " $C$ " and " $D$ " is interpreted to be volcanic rocks 1400 feet thick. The unshaded section below reflector " $D$ " is interpreted to be Paleozoic sediments. Graben-bounding faults are steeply dipping lines labeled V, W, X, Y, and Z. Modified from Kim (1985).

Figure 13. Effect of varying basin-fill thicknesses on potential reservoir temperatures. Note that for the assumed thermal conductivities (K) of basin-fill sediments (overburden) and bedrock (reservoir rock) the temperature at depth increases with increasing thickness of basin-fill sediments. For instance, with zero thickness (blue line) the temperature at a depth of 5 $\mathrm{km}$ is less than $200^{\circ} \mathrm{C}$, but for $1 \mathrm{~km}$ thickness (green line) the temperature would exceed $200^{\circ} \mathrm{C}$ at $5 \mathrm{~km}$, and for $3000 \mathrm{~m}$ thickness (orange line) the temperature would reach $200^{\circ} \mathrm{C}$ at a depth of only about $3.5 \mathrm{~km}$. For interpreted thicknesses of basin-fill sediment of 2000-3000 meters in parts of the GSLD, temperatures greater than $100^{\circ} \mathrm{C}$, capable of binary power production, may be expected at drilling depths of 2-3 km (Moore and Allis, 2011).

Figure 14. Map showing the extent of Pleistocene lakes in the Great Basin. UTTR/Dugway lands outlined in red (modified from Morrison, 1991). 
Figure 15. Map showing distribution of existing gravity stations (black dots) in and around the GSLD. UTTR/Dugway lands outlined in green. Cross-hatched areas are the focus areas identified based on geologic and geophysical information. Major roads in blue and red. Faults interpreted from gravity shown as dashed black lines and pink lines. Quaternary faults represented by dashed red lines. Note the sparsity of gravity stations south of Interstate 80 (blue line), including most of UTTR-S and Dugway Proving Grounds. The lack of gravity stations there precludes interpretation of subsurface structure. Gravity station locations from the Pan American Center for Earth and Environmental Sciences (PACES) website at University of Texas at El Paso:

[http://irpsrvgis00.utep.edu/repositorywebsite/Default.aspx]. 


\section{ACRONYMS}

API American Petroleum Institute

Dugway Dugway Proving Grounds

GSLD Great Salt Lake Desert

HAFB Hill Air Force Base

PACES Pan American Center for Earth and Environmental Sciences

UGS Utah Geological Survey

USGS United States Geological Survey

UTTR Utah Testing and Training Range

UTTR-N Utah Testing and Training Range-North

UTTR-S Utah Testing and Training Range-South 
This page intentionally left blank. 


\section{INTRODUCTION}

The purpose of this report is to summarize the current state of geologic knowledge concerning potential high-temperature geothermal development on the lands controlled by Hill Air Force Base (HAFB) at the Utah Testing and Training Range (UTTR) and the lands encompassed by the Dugway Proving Grounds (Dugway). This report is based on currently available published and publically available information. Most of the information presented here is purely geologic in nature. Therefore, the logistical issues (such as military exclusion areas, proximity to electrical infrastructure, and access) are additional considerations that are being addressed in a separate report that will be issued to HAFB by the SES Corporation.

Much of the data gathered for this assessment of geothermal potential has been compiled as thematic layers, all at the same scale, so that diverse information can be compared and analyzed by means of map overlays. The material for the thematic layers was identified from literature searches and from published and unpublished maps. Each layer was generated by INL's GIS Laboratory and subsequently compiled in an Adobe Illustrator file for ease of comparison and analysis. At present the map contains 11 layers of geographic information and 20 layers of geologic and geophysical information, each of which can be viewed independently or in association with any of the other layers. Many of the figures presented in this preliminary report were generated by exporting versions of this compilation map with selected thematic layers visible.

This report generally proceeds from regional to site-specific considerations, and is divided into five major headings: (1) Regional Setting; (2) Local Geology; (3) Geothermal Exploration Models; (4) Focus Areas on the UTTR and Dugway lands; and (5) Recommendations for Future Work. It is meant to be a framework into which new information developed over the next few months can be incorporated for the final report, which is due before the end of FY-2011.

\section{REGIONAL SETTING}

The UTTR/Dugway lands are located within the Great Basin of the Basin and Range Province in northwestern Utah (see Figure 1). Together, the Range and the Proving Grounds cover a large area of the Great Salt Lake Desert (GSLD) (see Figure 2). The UTTR is separated into two distinct areas, one north of Interstate 80 (UTTR-N) and one south of Interstate 80 (UTTR-S). 


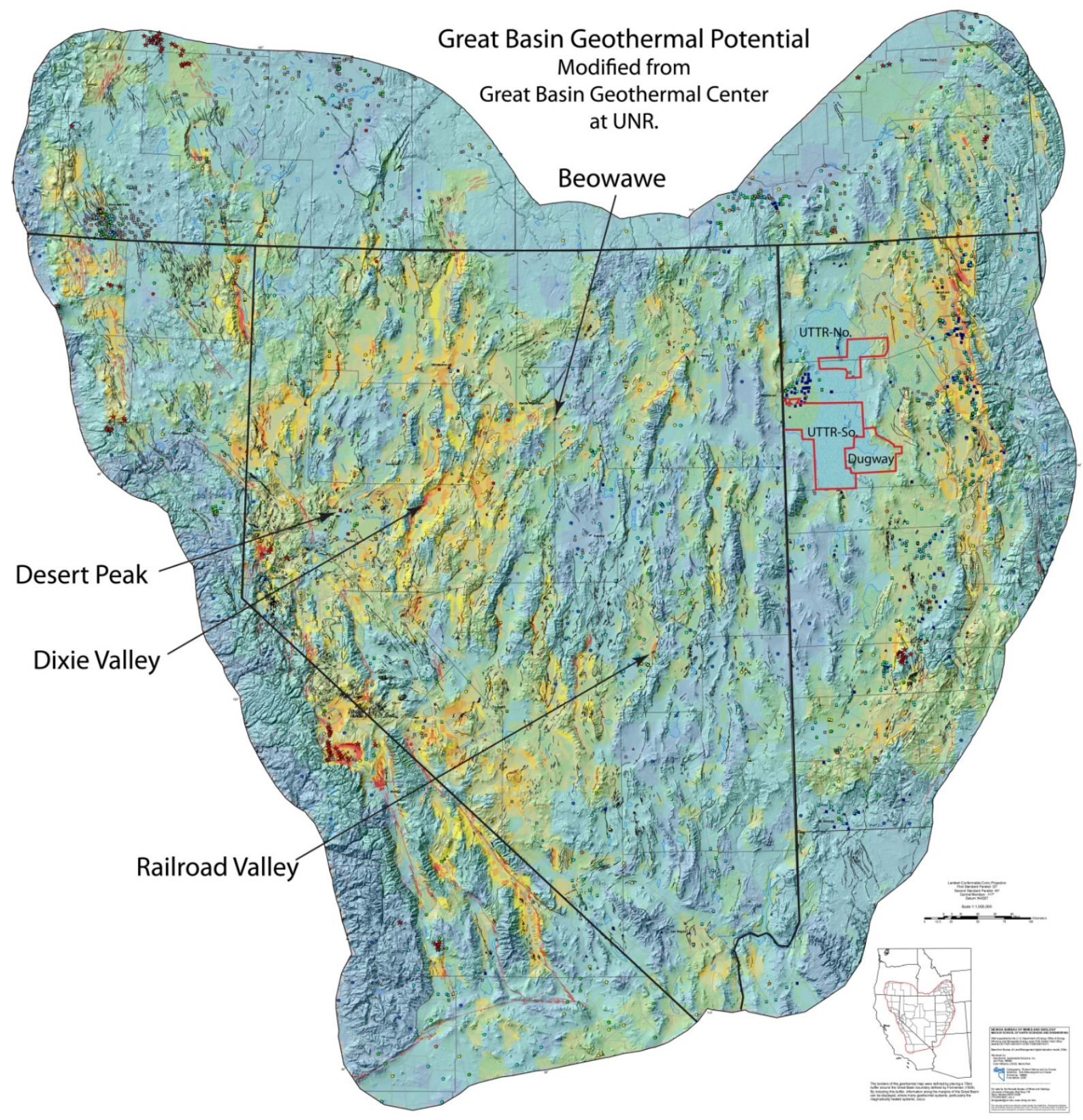

Figure 1. Map of the Great Basin showing geothermal potential based on a number of geothermal indicators. Geothermal potential indicated by colors with warm colors having higher potential than cool colors. Also identified are several geothermal fields discussed in the text (modified from the Great Basin Geothermal Center's website at: http://www.nbmg.unr.edu/dox/m151/m151plate.pdf). 


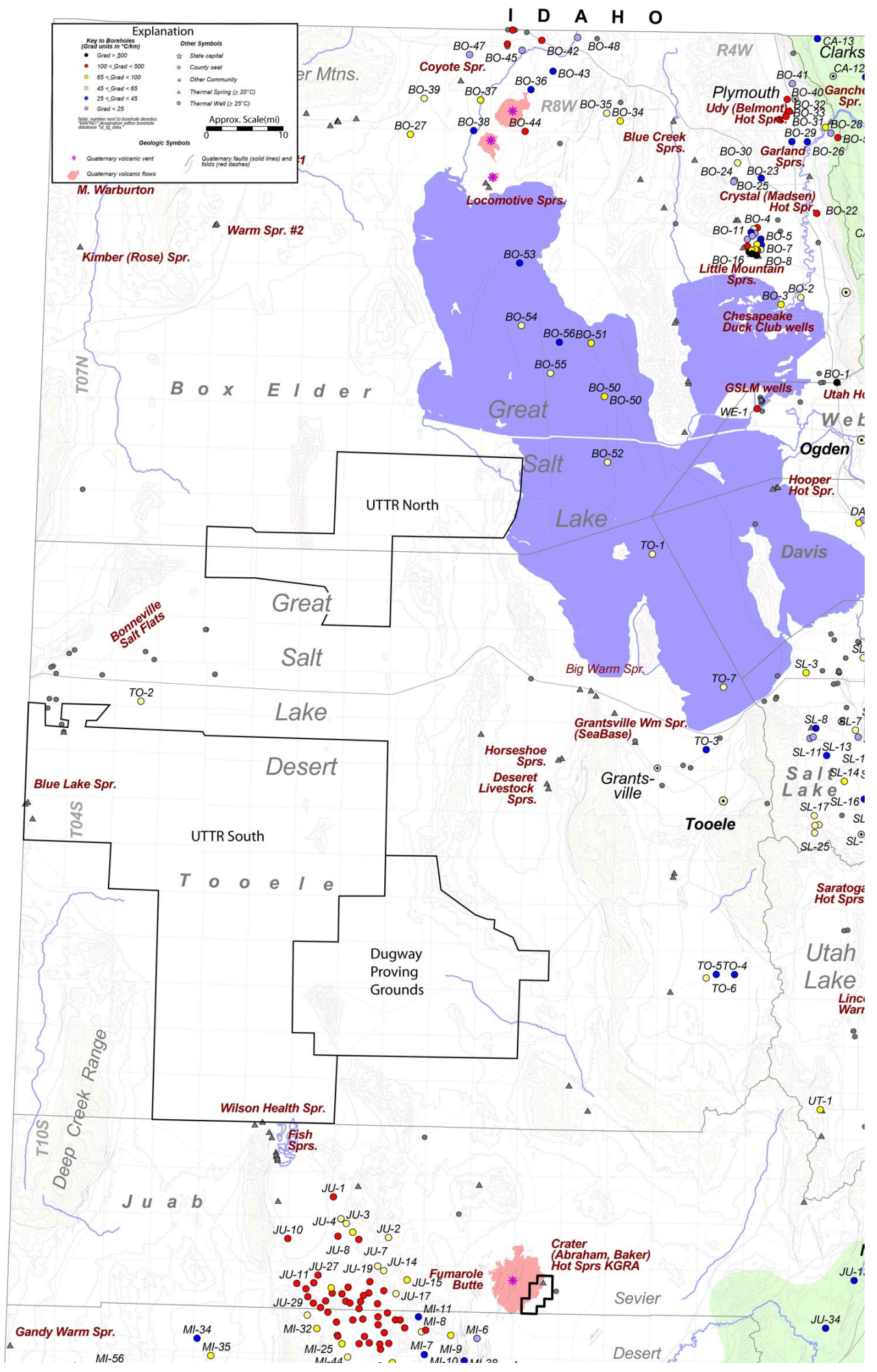

Figure 2. Map showing the UTTR/Dugway areas within the GSLD. Also shown are locations of thermal springs (color coded for temperature) and wells (color coded for geothermal gradient). Modified from the Utah Geological Survey's website at http://geology.utah.gov/emp/geothermal/pdf/ut_geoth tg.pdf. 
The entire Great Basin, which encompasses most of Nevada and the western half of Utah, is an area of thin crust, anomalously warm upper mantle rocks, high heat flow (see Figures $3 \mathrm{~A}$ and 3B), and numerous geothermal systems, some of which host geothermal power plants (Hammond and Thatcher, 2004; Sass et al., 1971, 1999). In addition, persistent seismicity throughout the basin attests to active crustal extension and normal faulting. Extension rates are generally greatest near the margins of the Great Basin, but locally high rates occur throughout the area.

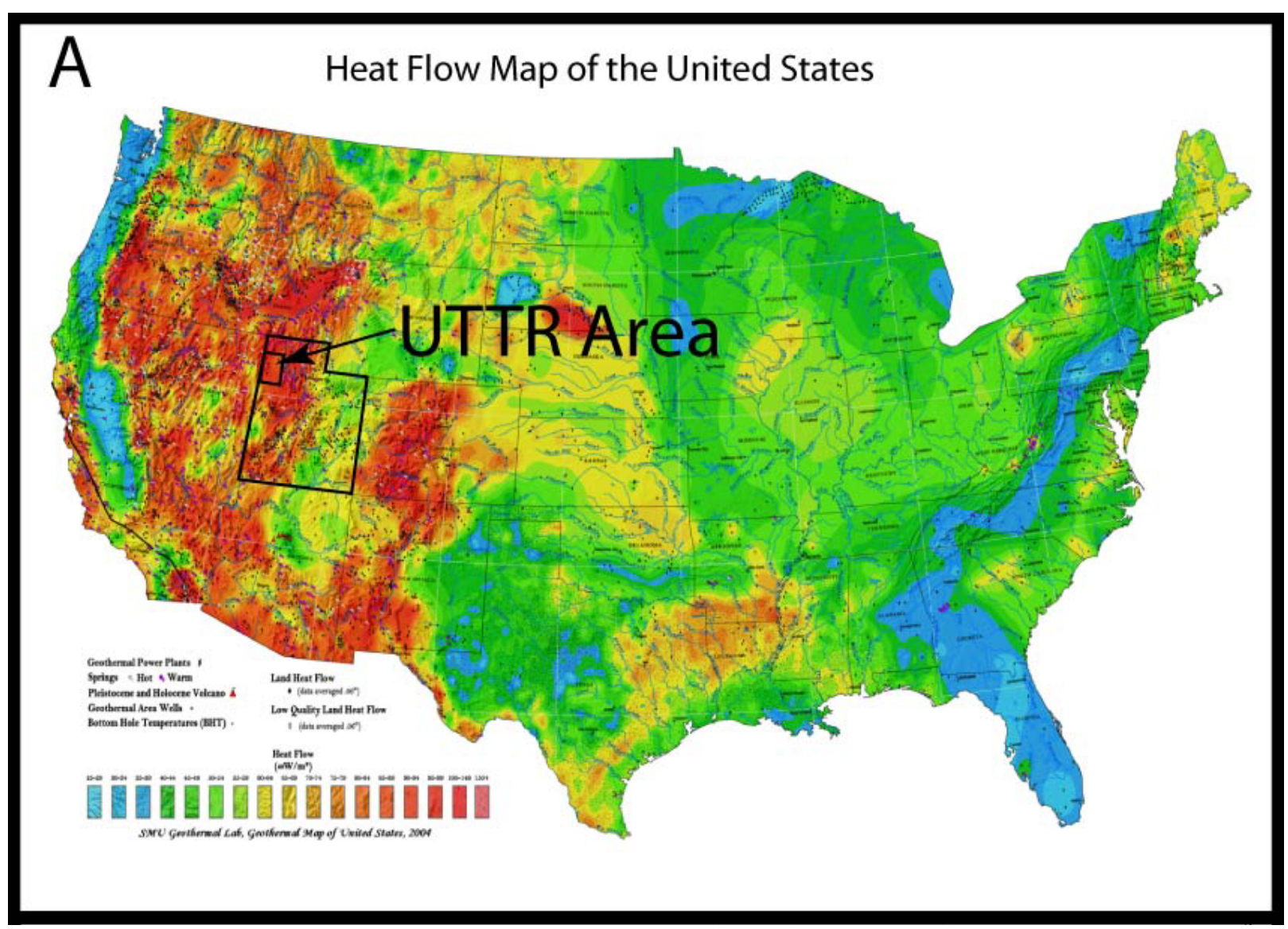

Figure 3A. Heat flow map of the United States, with the state of Utah and the UTTR area identified. Heat flow is the amount of heat being conducted from depth and escaping from the earth's surface. It is usually given in units of milli-watts per square meter of the earth's surface $\left(\mathrm{mW} / \mathrm{m}^{2}\right)$. Warmer colors represent areas with high heat flow and cool colors represent areas with lower heat flow. The UTTR area is characterized by high heat flow of $90-100 \mathrm{~mW} / \mathrm{m}^{2}$, similar to most of the Basin and Range province. Modified from the Southern Methodist University Geothermal Laboratory website at: http://smu.edu/geothermal/heatflow/geothermal_all_us_clipped_150dpi pagesize legend.gif. 


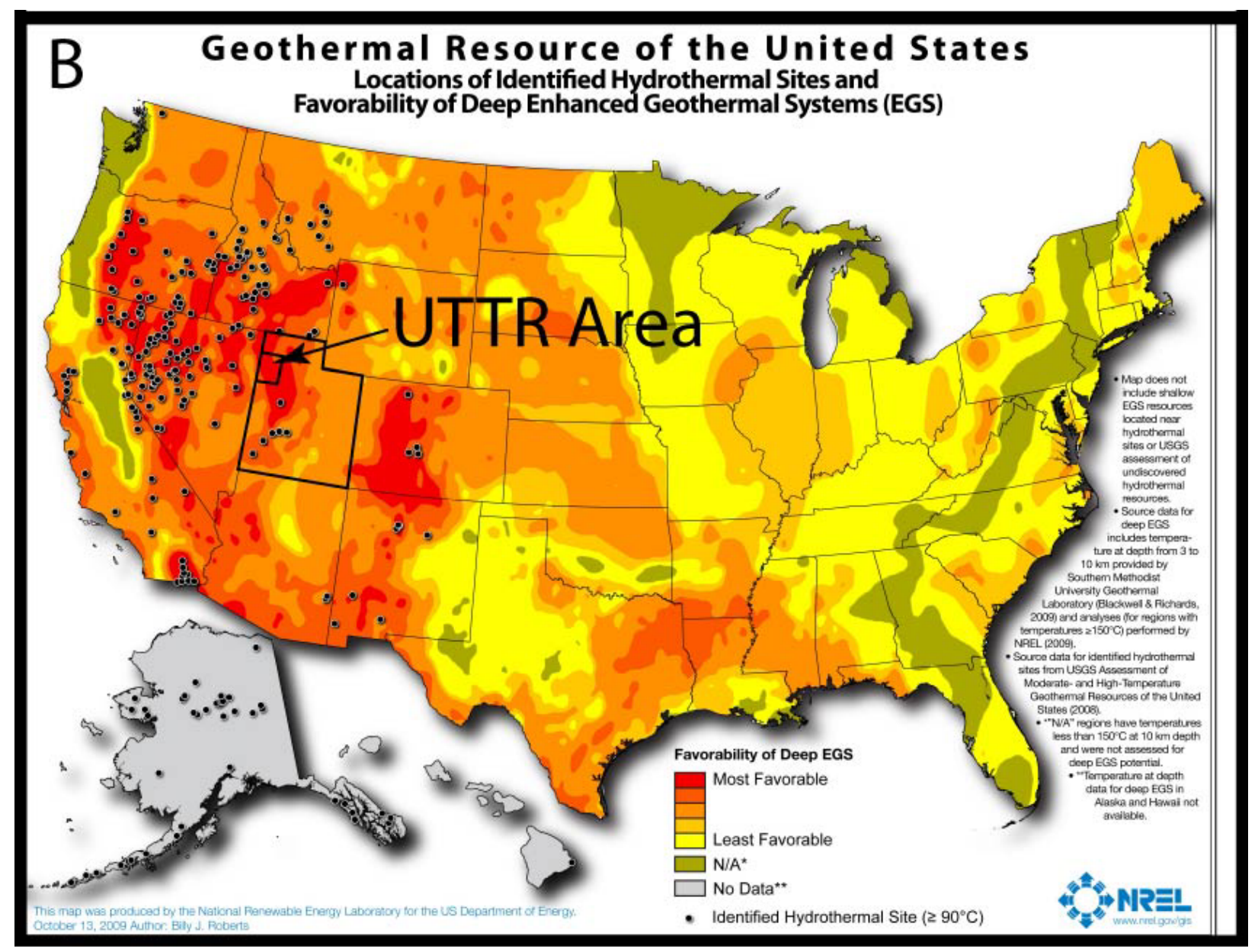

Figure 3B. Map of the United States showing favorability for discovery of deep enhanced geothermal systems. An "enhanced" geothermal system is one that possesses temperatures sufficiently high for electrical generation, but may need artificially induced permeability (fracturing) to allow sufficient flow of geothermal fluids to the surface. Favorability is based on a number of criteria, including temperature at a depth of 3 to $10 \mathrm{~km}$. The UTTR area of Utah is among the most favorable in the U.S. Modified from the National Renewable Energy Laboratory website at http://www.nrel.gov/gis/images/geothermal_resource2009-final.jpg.

The GSLD is a structural basin (one of the larger basins within the Great Basin) which, like most basins of the province, has been filled with a thick sequence of Neogene, Quaternary, and Holocene sediments. Significant recent sediments covering the GSLD are fine muds and evaporite deposits associated with growth and desiccation of Lake Bonneville during Pliestocene glacial cycles.

The Great Basin Center for Geothermal Energy, located at the University of Nevada, Reno, has produced a map (refer to Figure 1), which shows greater potential for the discovery of geothermal systems with warm colors and lesser potential with cool colors. The center's assessment is that the greatest discovery potential lies in the western part of the Great Basin (i.e., western Nevada) and along the Wasatch front in the state of Utah. This is because the geothermal systems in the Great Basin are deep-circulation systems that depend on circulation of groundwater to great depths along fault zones for their existence. Fluids must be able to circulate to depths as great as $9 \mathrm{~km}$ to be heated to temperatures sufficient for primary electric generation 
(see Figure 4). Therefore, faults must extend through the upper crust and maintain open flow conduits in the current stress environment. Deep circulation and heating of significant quantities of groundwater can occur only on faults that repeatedly rupture (i.e., active faults) in current stress conditions, which keeps permeability pathways open. Therefore, areas with a higher strain rate are more favorable than areas with lower strain rates. Active faults (i.e., Quaternary and Holocene in age) occur mostly along the eastern margin and in the western part of the Great Basin, thus providing for the higher potential assessed in those areas.

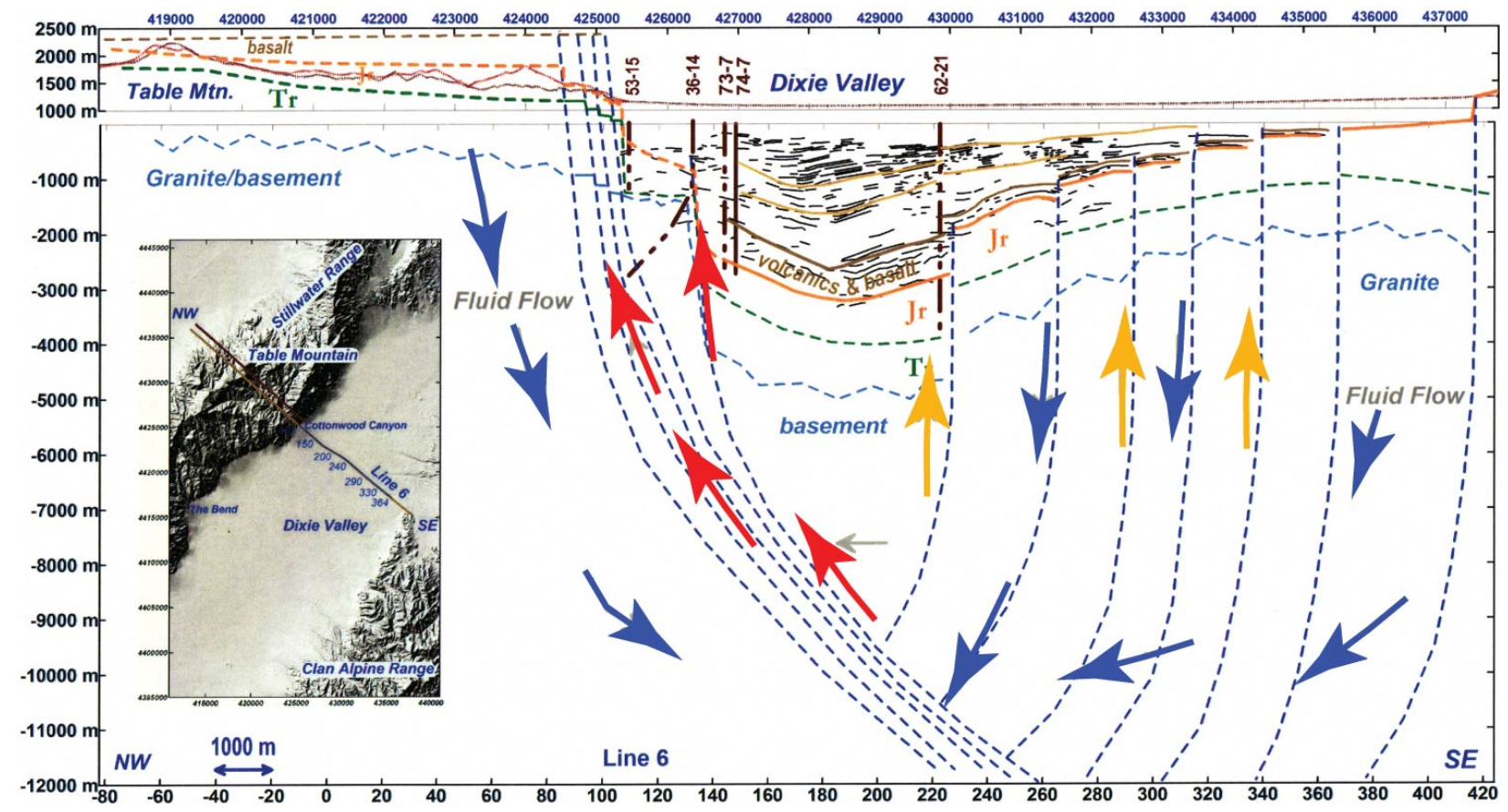

Figure 4. Cross-section of the Dixie Valley, Nevada, geothermal field with interpreted fluid flow vectors. Based on known geothermal gradients at Dixie Valley, cool water (indicated by blue arrows) migrates to great depths $(\sim 9 \mathrm{~km})$ where it is heated, and returns by flowing up the basin-bounding fault zones (indicated by red arrows). Temperatures of the geothermal fluids exceed $200^{\circ} \mathrm{C}$ in some areas, and a $63 \mathrm{MW}$ primary generation power plant is in operation there. This cross section is drawn perpendicular to the fault zone. Just as important is migration of fluids downward within the fault zone in areas adjacent to the geothermal field and then upward along the fault zone in the area of the geothermal reservoir (modified from Blackwell, 2007).

A closer view of the UTTR/Dugway areas on the geothermal potential map produced by the Great Basin Center for Geothermal Energy is presented in Figure 5. It shows areas with greater potential for the discovery of geothermal systems with warm colors and lesser potential with cool colors. The assessment is based on a number of geothermal indicators, including geothermal gradient, heat flow, proximity to thermal springs and wells, and proximity to Quaternary (active) faults. As can be seen by the limited number of heat flow, well, and spring symbols within and near UTTR/Dugway lands, very little such information is available for the UTTR. Although the map shows that no active faults have been recognized in the UTTR/Dugway lands, many are recognized in the adjacent mountain ranges, and the Quaternary faults south of the GSLD trend towards the UTTR. It is likely that these faults extend beneath the UTTR and Dugway, but are buried by younger sediments. The small ranges within the GSLD are the tops of fault-bounded mountain ranges, and the faults that bound them are buried beneath the young sediments. 


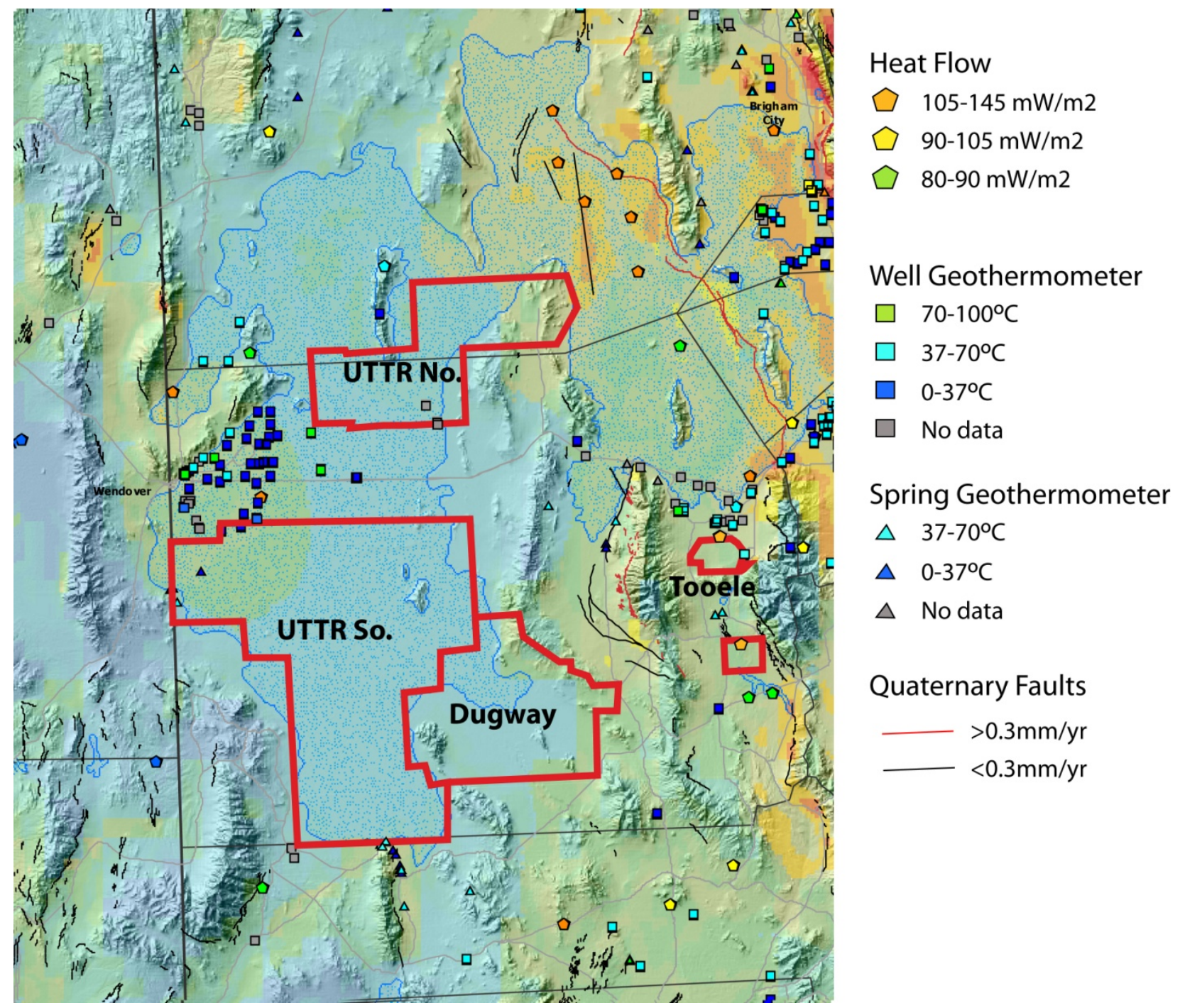

Figure 5. Close-up view of the UTTR/Dugway areas on the map shown in Figure 1.

As interpreted by the Great Basin Center for Geothermal Energy, the UTTR/Dugway has been assessed a geothermal potential of marginally favorable to favorable for discovery of a geothermal system of $>150^{\circ} \mathrm{C}$ (i.e., the warmer the color on the map, the greater its favorability). The ranking is influenced by nearby areas of moderate to high heat flow (indicated by orange pentagons) and Quaternary faults with $>0.3 \mathrm{~mm} / \mathrm{yr}$ strain rates (indicated by red lines) and many Quaternary faults that may or may not be as active (indicated by black lines). As such, the most favorable areas identified by the Great Basin Center are the westernmost area of UTTR-S, the easternmost area of UTTR-N, and along the northeastern boundary of Dugway. But note that the entire GSLD is surrounded by areas judged to be favorable to highly favorable. A possible contributor to the lower favorability rating in the center of the GSLD is that there is a lack of data for this area, probably due to its remoteness, sediment cover, and limited access. Wells and springs exist in the area, but few have been sampled and analyzed for geothermal exploration. Another consideration is that almost all of the site is within the GSLD, a pluvial system (playa) in which evidence of surface ruptures due to faulting or to outflow of geothermal waters is quickly buried or modified by playa activity. Some of the faults south of the GSLD trend 
towards the UTTR; it is likely that they extend beneath the UTTR and Dugway, but are buried by younger sediments. The small ranges within the GSLD are the tops of fault-bounded mountain ranges, and the faults that bound them are buried beneath the young sediments.

\section{LOCAL GEOLOGY}

The UTTR/Dugway lands, and the encompassing GSLD (see Figure 6), occur in an area with a complex geologic history (see Figure 7). During Paleozoic and Mesozoic time, most of the area was beneath a shallow sea and the deposition of thick sequences of marine carbonate (i.e., limestone, dolomite) and clastic (i.e., shale, sandstone, conglomerate) sediments provide a record of those times. In the late Mesozoic and early Paleogene timeframe, the entire area was subjected to compression from the west, most likely due to subduction of the oceanic plate beneath the western United States. Compression associated with the subduction caused intense folding and thrust-faulting of the Paleozoic strata in a large belt (known as the Overthrust Belt or the Sevier Thrust system) extending through northern Utah. These folded and thrust-faulted sequences of sediments make up most of the bedrock beneath the GSLD.

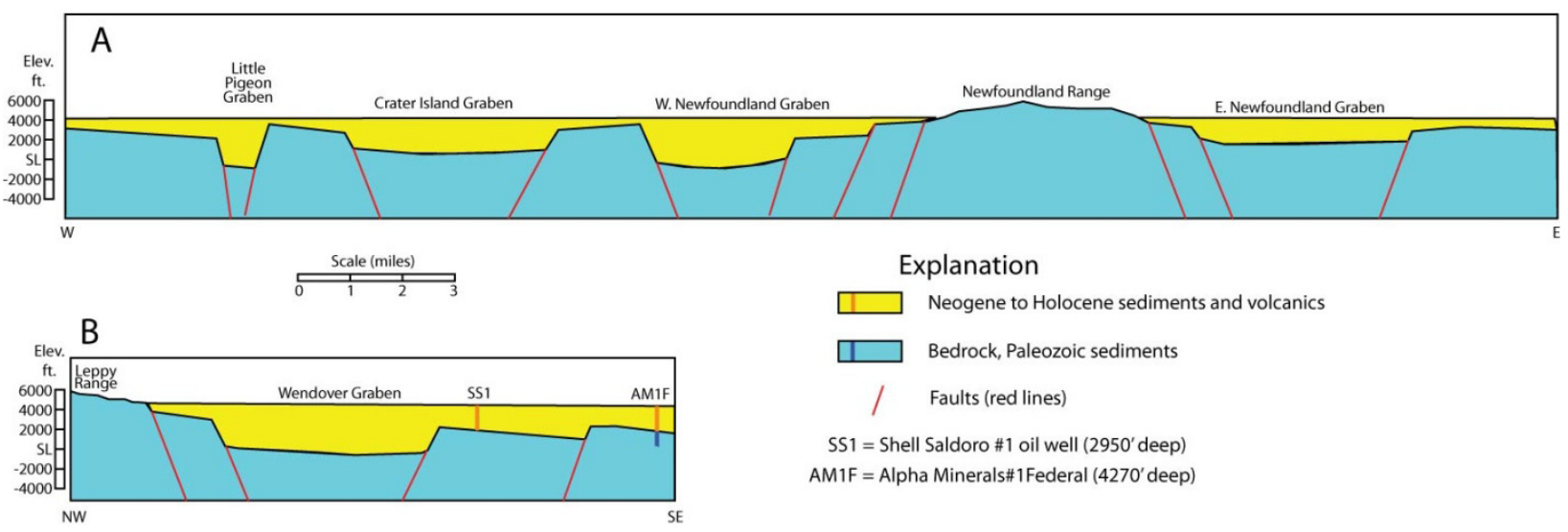

Figure 6. Simplified geologic cross-sections of the GSLD: (A) East-West cross-section through Newfoundland Mountains and part of UTTR-N; (B) Northwest-trending cross-section through the Wendover Graben, just north of UTTR-S. Petroleum exploration well SS1 projected into the cross-section from the south. Petroleum exploration well AM1F projected into the cross-section from the north (Modified from Cook et al., 1964). Refer to Figure 8 for locations of these cross sections. 


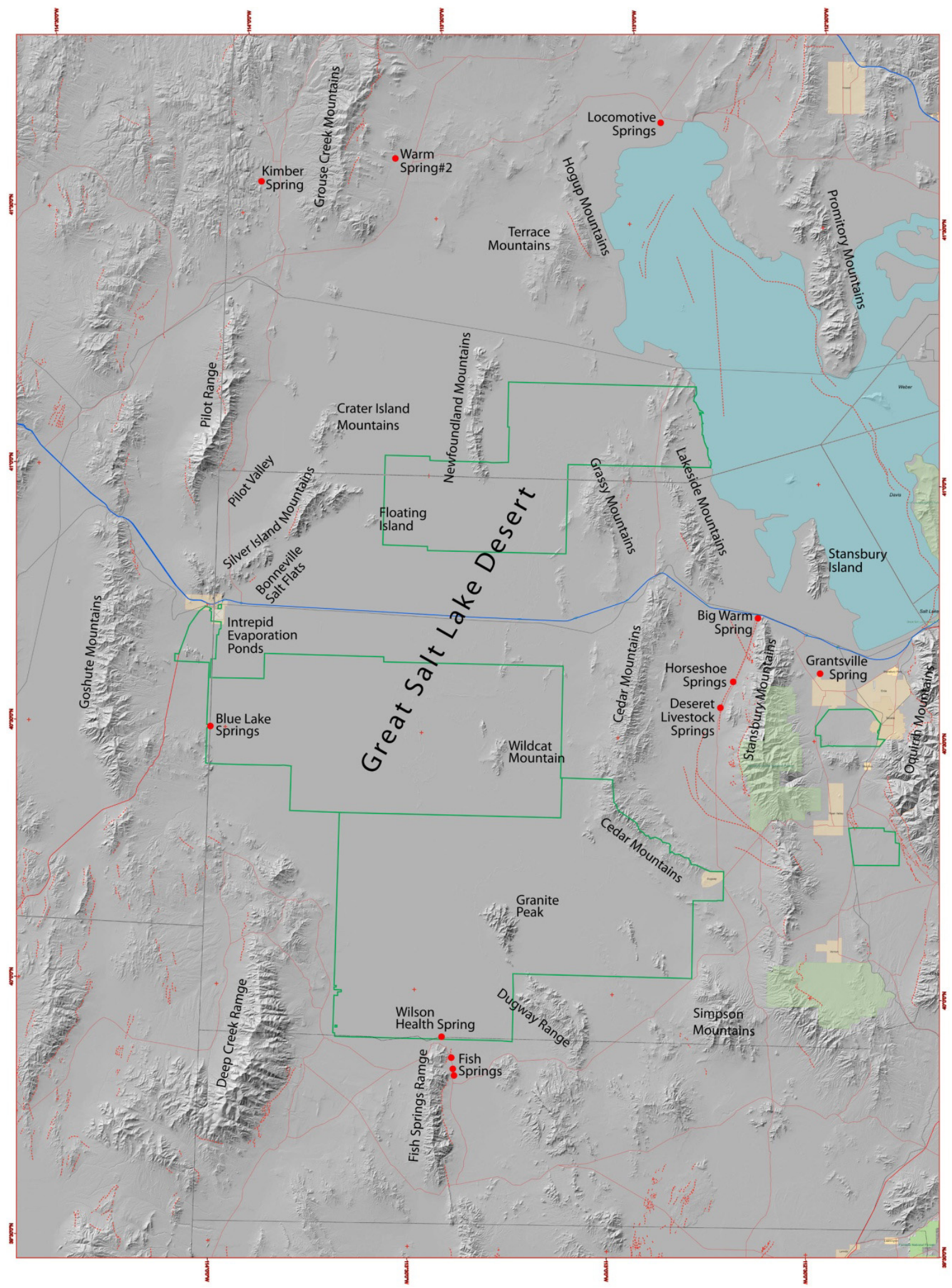

Figure 7. Map showing the geographic features of the UTTR/GSLD area. UTTR/Dugway outlined by green lines, I-80 identified by the blue line, and all other minor roads depicted with solid red lines. The Great Salt Lake is shaded blue, towns via tan, and national forests with green. Quaternary faults are indicated by dashed red lines and thermal springs by red dots. 
After the Overthrust Belt was formed, the region was in a transitional state between the compression that ended around 40 million years ago and the extension that would begin about 20 million years ago. During that time, and especially just preceding the extensional period, volcanism in this area was widespread. The subsequent east-west directed extensional stresses that produced the Basin and Range Province and the Great Basin continues today. As that extension progressed, the crust responded by breaking into north-south elongated blocks that were raised (i.e., mountain ranges), lowered (i.e., intervening basins), or tilted in a domino style. The north-trending mountain ranges surrounding the GSLD and the ranges within the GSLD were produced by this process. As the mountain ranges were uplifted, they were weathered and eroded, producing large volumes of silts, sands, gravels, and clays that filled the intervening basins. Sporadic volcanism also produced volcanic rocks of various types that accumulated in the basins.

Additionally, the basins were commonly closed depressions and at times held lakes and playas where lacustrine sediments (i.e., freshwater limestones, clays, silts, and sands) accumulated. In the GSLD, all of those types of rocks are encountered in deep wells (such as petroleum exploration and water wells), indicating that the UTTR/Dugway lands are underlain by thousands of $\mathrm{ft}$ of these basin-filling sediments and volcanics. The most recent of those sediments (approximately 2 million years ago to the present day) were deposited from Lake Bonneville, which covered the GSLD during glacial cycles, and helped to produce the flatfloored topography between the adjacent and interior mountain ranges. Much of the surficial sediment is Holocene in age, deposited in active playas and overflow areas from the Great Salt Lake that cover, remodel, and level the surface over annual and decadal time scales.

Figure 8 provides a detailed map showing important geologic features and data relevant to the identification of geothermal exploration areas. Major grabens are identified with black text, interpreted graben-bounding faults are identified by dashed black lines (Cook et al., 1964), and by pink lines (interpreted from the isostatic gravity map for this study), each with the ball on the downthrown side. Quaternary faults are represented by faint dashed red lines, earthquake epicenters by green circled dots, springs by blue dots, oil and gas wells by black circles, and depth to the bedrock at some oil and gas wells by maroon-colored text. Further, heat flow values (Henrikson and Chapman, 2002) in $\mathrm{mW} / \mathrm{m}^{2}$ are shown by large black numbers in italics; bottomhole temperatures are shown by large red numbers (Henrikson and Chapman, 2002); seismic lines of Fitter (1985), Kim (1985), and Rene et al. (1988) are shown by red lines just north and west of UTTR-N; and major roads are shown by solid blue, grey, and red lines. The focus areas are identified by a fine hatch pattern. 


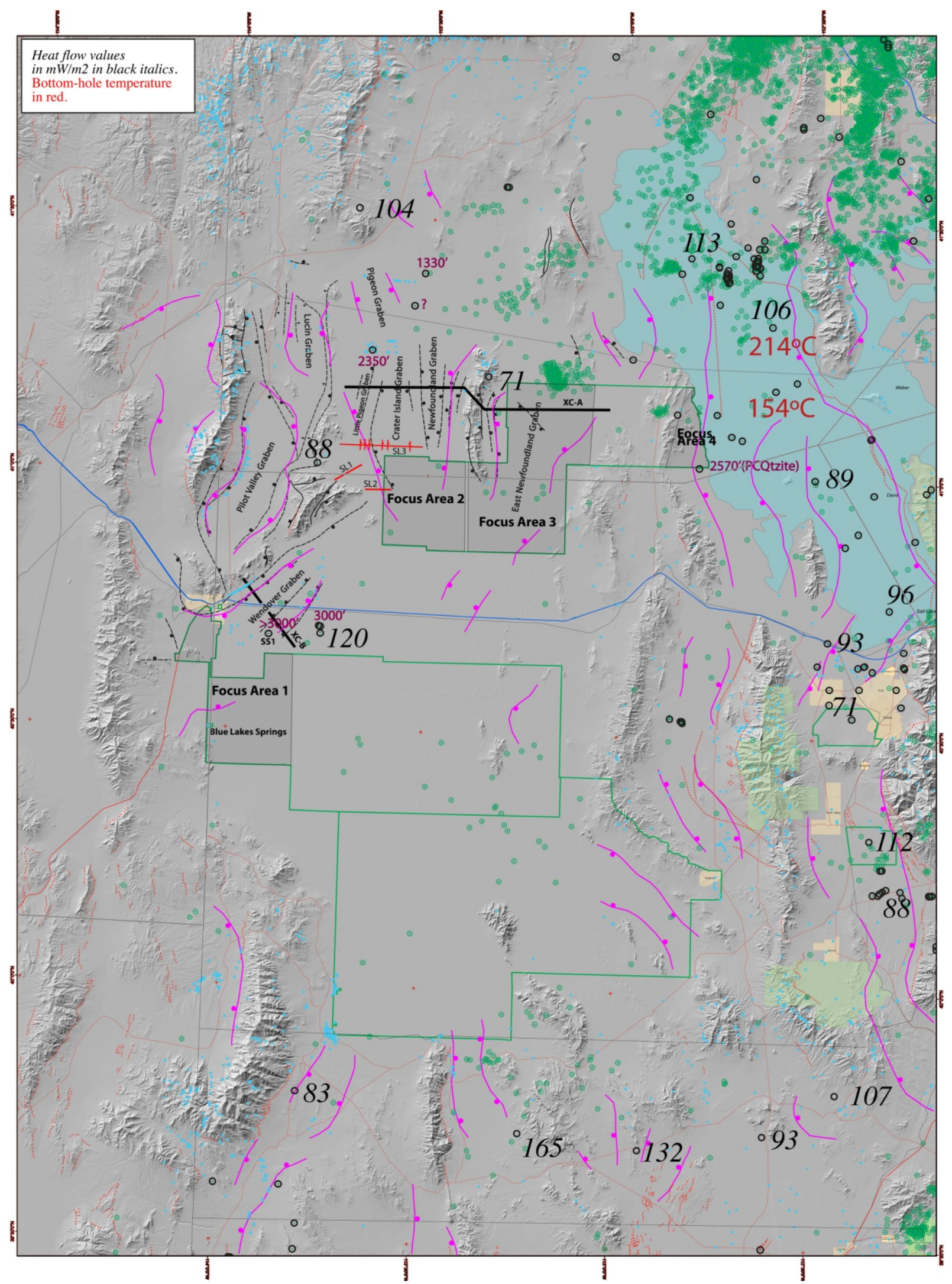

Figure 8. Map showing important geologic features and data relevant to identification of geothermal exploration areas. The locations of the cross-sections shown in Figure 6 are labeled XC-A and XC-B. 


\section{GEOTHERMAL EXPLORATION MODELS}

There are a variety of different geothermal explorations models for basin and range deep circulation geothermal systems. These "conceptual" models, as they are sometimes called, are used to define the salient features of the geology, temperature regimes, and hydrogeology that must be present in order for a viable geothermal exploration target to exist. They incorporate the characteristics of known geothermal systems. Conceptual geothermal models all recognize that a geothermal system with commercial potential must have sufficient heat, water, and permeability. Neither is sufficient on its own; instead, it is the coincident occurrence of multiple characteristics that contribute to the existence of a geothermal reservoir capable of electrical generation.

\section{Geothermal Exploration Model 1 - Surface Geothermal Features.}

Precept: Fumaroles, hot springs, and warm springs all represent leakage of hot water or steam from a deeper, larger geothermal circulation system. This model has been the main exploration model in the past for the Great Basin and has lead to the discovery of several good geothermal reservoirs. Dixie Valley (refer to Figures 1 and 4) and Beowawe (refer to Figure 1) are examples of this phenomenon. At Dixie Valley, the locations of fumaroles and hot springs focused efforts on a particular area, and application of thermal gradient drilling, structural geologic models, geochemical characteristics, and geophysical surveys lead to successful deep exploration and production wells. The occurrence of hot and warm springs along the margins of the GSLD (i.e., Blue Lakes and Fish Springs, etc., shown in Figure 2) are obvious areas of focus for geothermal exploration. Additionally, surface expressions of potential geothermal systems in the GSLD may actually exist, but may be unrecognized because of the lack of focused exploration in the area, because such surface expressions (i.e., warm water outflow zones, sinter deposits, springs, mounds developed around springs, etc.) may be masked by periodic waxing and waning of the Great Salt Lake and seasonal flooding events, and because they may be quickly buried by the deposition of playa sediments. Therefore, the scarcity of surface geothermal expression in and near the UTTR/Dugway lands does not preclude the existence of these phenomena.

\section{Geothermal Exploration Model 2 - Thermal Gradient.}

Precept: Areas of high geothermal gradient are likely to lie above deep, hot geothermal systems. Some geothermal systems have no surface expression (i.e., Desert Peak shown in Figure 1) and have been found by siting deep exploration wells in areas where thermal gradient drilling revealed high temperature gradients. Subsequent deep drilling, geophysics, and structural analysis have shown that the distribution of faulting and fault intersections in the subsurface control the location of the system. This leads to a third exploration model.

\section{Geothermal Exploration Model 3 - Finding Fault.}

Precept: Deep circulation geothermal systems can occur in the permeable pathways along active fault zones and along the intersections of multiple fault zones. In areas where surface geothermal expression is absent or sparse, and where thermal gradient information is sparse (i.e., the GSLD), a viable method of locating areas for focused exploration is analysis of geologic structure and faulting patterns. That is why the geophysical surveys - especially the gravity surveys - of the GSLD are so important. 
The distribution of gravity intensity (see Figure 9) is controlled mostly by the difference in density between the bedrock of the mountain ranges and basin filling sediment. The elongate negative gravity anomalies and the steep gravity gradients separating the uplifted bedrock areas from the down-dropped basin floors can be used to define the locations of grabens and major faults. Interpretations of the locations of these grabenbounding fault zones (see Figure 10), and areas of potential intersection and bifurcation of fault zones, from gravity variations provides focus for concentrated geothermal exploration. Gravity data, when combined with other data (such as the locations of earthquake epicenters, proximity to known active faults, distribution of springs, visible lineaments indicating minor faulting in the near-surface environment, and deep subsurface information from existing oil and gas wells), provides a strong rationale for further exploration focus.

\section{Geothermal Exploration Model 4 - Deep Sedimentary Basins.}

Precept: The low thermal conductivity of unconsolidated to poorly consolidated sediments in deep basins (such as those in the Basin and Range Province and that beneath the GSLD) serve as an insulating blanket, and cause an anomalously high increase in temperature with depth. This is a new model recently proposed by Joe Moore of the Energy and Geoscience Institute at the University of Utah, and Rick Allis, Utah Geological Survey Director (Moore and Allis, 2011).

In addition to recognition of the insulating nature of basin sediments, this model advocates the search for a different kind of permeability (i.e., stratigraphic permeability instead of fault permeability) as a viable exploration target in deep basins. Such stratigraphic permeability could be present in the deep parts of the basin-fill sediments or in the bedrock beneath the sediments. Examples would include volcanic or landslide breccias near the bottom of the basin-fill sediments and bedrock units with high permeability (i.e., karstic limestones, fractured clasitic or carbonate strata, and sandstones with large, interconnected pore spaces). Such permeable strata can be recognized by mapping bedrock units in adjacent mountain ranges, by using geophysical logs of petroleum exploration wells, and perhaps by various surface electrical geophysical surveys. This model changes the emphasis of exploration from the search for heat in places where permeability is likely to the search for permeability in places where sufficient heat is expected or likely. The model is likely to be applicable to the UTTR/Dugway effort because sedimentary basin fill is over $2 \mathrm{~km}$ thick in some identified graben, and because the limited subsurface temperature data for the area (based on geophysical logs of a few petroleum exploration wells and deep brine wells) suggest high thermal gradients and heat flow. 


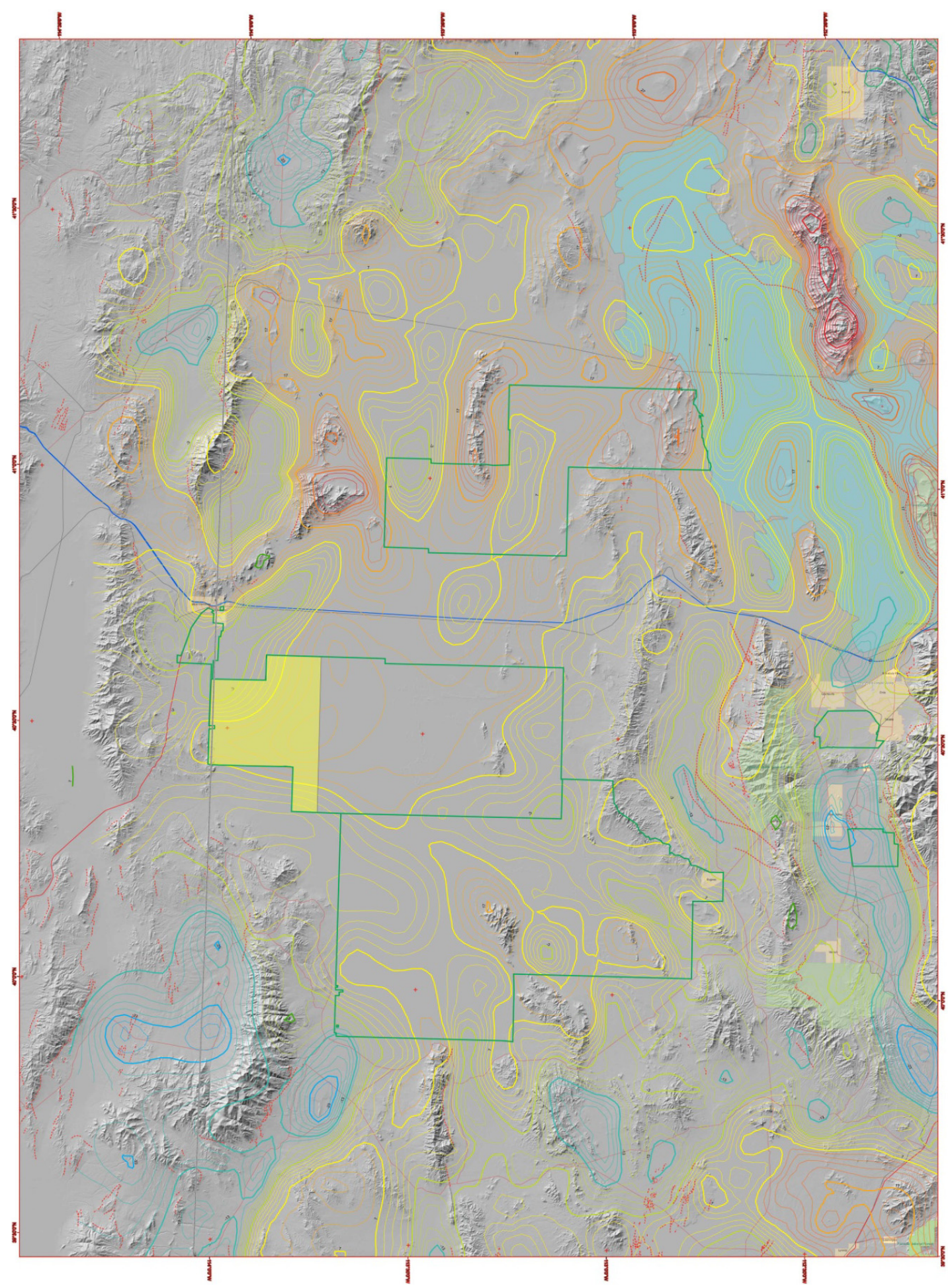

Figure 9. Isostatic gravity map of the UTTR/Dugway area. The contours show lines of equal intensity of gravitational force, and are color coded with higher gravity intensities in yellow, orange, and red colors, while lower intensities are identified in green and blue colors. Note that the denser rocks of the mountain ranges are characterized by high gravity values (i.e., orange and red contours), while the less-dense valley fill material between ranges is characterized by low gravity values (i.e., yellow, green, and blue contours). Gravity data downloaded from the PACES website at the University of Texas at El Paso and contoured by the INL GIS laboratory. 


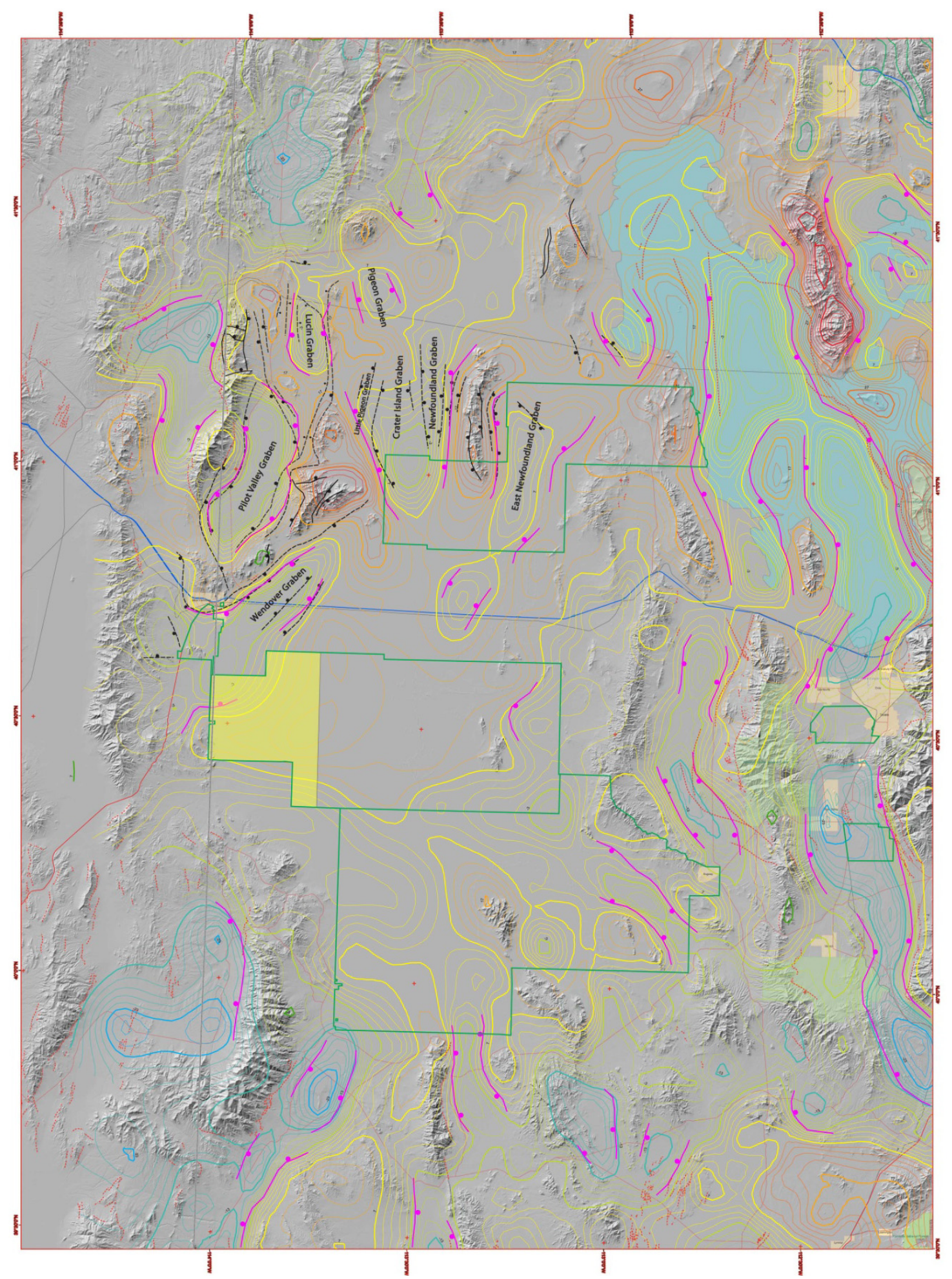

Figure 10. Isostatic gravity map of the UTTR/Dugway area with interpreted graben-bounding faults. Based on experience in many basins and on geophysical theory, faults coincide with the zones of steepest gravity gradient between the ranges and intervening valleys. Faults interpreted by Cook et al. (1964) in dashed black lines. Faults interpreted for this study in pink lines. In both cases, the downthrown side is indicated by the balls attached to the lines. The yellow-shaded area in western UTTR-S is the area of geothermal assessment focus based on proximity to electric infrastructure. 


\subsection{Characteristics Relevant to Discovery of Geothermal Systems on UTTR/Dugway Lands}

\section{Location within the Great Basin (All geothermal exploration models apply)}

As discussed in the section on Regional Setting, the Great Basin is a prime exploration area for deep-circulation geothermal resources. The location of UTTR/Dugway lands within the Great Basin, near deep-seated faults, near regions of high extension rates, and over horst- and grabenbounding faults beneath the basin-fill sediments are all relevant to the discovery of geothermal resources. It is also relevant that known geothermal systems occur in the areas south of the GSLD in south-central and southwestern Utah. The most notable of these are Roosevelt Hot Springs, which hosts a single-flash power plant producing $26 \mathrm{MW}$ of electrical power, and Sulphurdale/Cove Fort, which hosts a binary geothermal power plant producing $10 \mathrm{MW}$ (Blackett and Wakefield, 2002; Utah Geothermal Working Group, 2005).

\section{Basin structure (Geothermal Exploration Model 3 applies)}

Although active sedimentation processes within the playa environment of the GSLD have buried extensional faults beneath thick sedimentary sequences and have masked surface evidence for the locations of the faults, their presence and location are revealed by other information. First, the mountain ranges within the GSLD (refer to Figure 6) are the tops of uplifted, fault-bounded blocks (horsts) between deep basins (graben). Second, the existing gravity data for the area (refer to Figures 9 and 10) reveal the locations of the deep graben and their bounding fault systems. Figure 8 provides the interpreted locations of faults, graben, and horsts beneath the GSLD sediments. Third, several faults recognized in the area surrounding the GSLD project into, and are buried by young sediment. Taken together, this information permits the development of a model for the basic structure of the GSLD basin.

Additionally, gravity surveys, seismic studies, and several deep oil and gas wells in the GSLD shows that the basin geology has characteristics similar to those associated with known geothermal systems in the Great Basin. For instance, it is common for Great Basin geothermal systems to occur along buried faults that lie basin-ward of the fronts of nearby mountain ranges. These are the faults that accommodate most of the displacement between the deepest part of the basin and the adjacent mountain range.

The GSLD gravity map (refer to Figures 9 and 10) and the interpreted cross sections (refer to Figure 7) show that the same situation exists here. For example, the faults bounding the Wendover Graben, the Crater Island Graben, the Newfoundland Graben, and the East Newfoundland Graben all lie several kilometers outboard of adjacent mountain ranges and are buried beneath sediments of the GSLD. Additionally, the basin structure is complex with merging and intersecting graben-bounding faults in common with other places in the Great Basin where geothermal systems occur.

\section{Thermal gradient and heat flow (Geothermal Exploration Model 2 applies)}

Although little information is available concerning subsurface temperatures in the GSLD, temperature gradients have been determined for several oil exploration wells in western Utah and the Great Salt Lake area (Henrikson and Chapman, 2002). Their data show values of $\sim 35^{\circ} \mathrm{C} / \mathrm{km}$ (higher than average continental crustal gradient) in the Basin and Range of western Utah and 
$60^{\circ} \mathrm{C} / \mathrm{km}$ (over twice the average gradient for the continental crust) for wells beneath the Great Salt Lake. These data are converted to heat flow (Henrikson and Chapman, 2002), which ranges from 70 to $120 \mathrm{~mW} / \mathrm{m}^{2}$ in the GSLD area, and the highest heat flow determination is in a well (i.e., AMF1) near the Wendover Graben (refer to Figures 8 and 11).

In addition, temperatures in several deep brine wells, shallow brackish-water wells, one petroleum exploration well (see Figure 11), and springs in the Wendover Graben area suggest the presence of high thermal gradients in the area. For example, Deep Brine Well 3 (or DB3 in Figure 11) has a temperature of $88^{\circ} \mathrm{C}$ at a depth of 500 meters, suggesting a thermal gradient as high as $176^{\circ} \mathrm{C} / \mathrm{km}$ (Turk, 1973). Therefore, temperatures of $200^{\circ} \mathrm{C}$ or higher are possible beneath the $\sim 2 \mathrm{~km}$ of sediment in the Wendover Graben. 


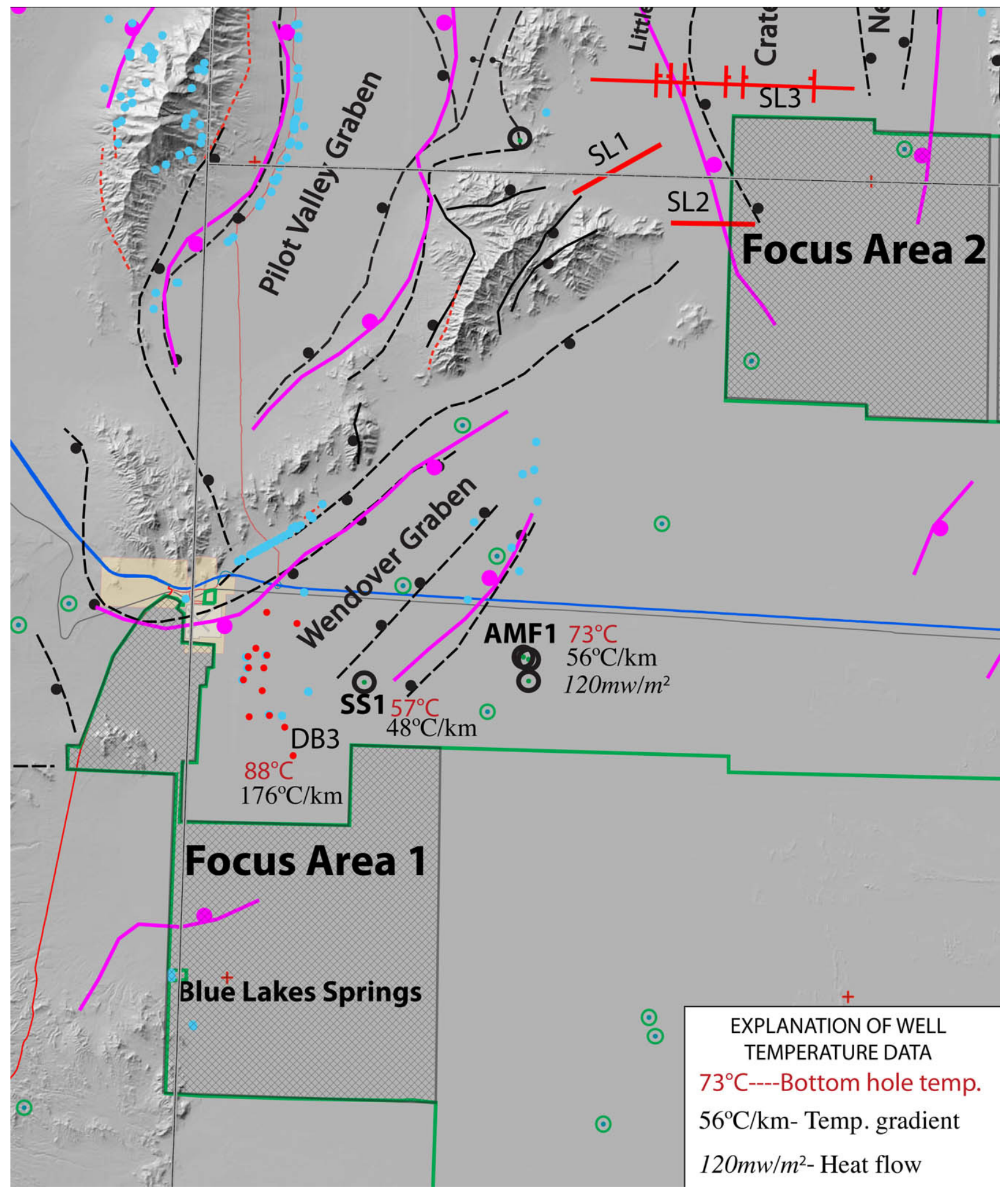

Figure 11. Detailed map of the Wendover Graben area and Focus Area 1. Graben-bounding faults shown by black dashed lines (Cook et al., 1964) and pink solid lines (this study); springs identified by blue dots, earthquake epicenters by green circles, seismic lines by red lines labeled SL1 through SL3, oil wells by heavy black circles, deep brine wells by red dots (DB3 = Deep Brine Well \#3; SS1 = Shell Salduro \#1; AMF1 = Alpha Minerals Federal \#1). 


\section{Thickness of basin-fill sediments (Geothermal Exploration Model 4 applies)}

Gravity modeling (Cook et al., 1964), seismic surveys (Fitter, 1985; Kim, 1985; and Rene et al., 1988), and several deep oil and gas wells provide information on the thickness of basin-fill sediments in the GSLD. The gravity modeling suggests that the deepest parts of the graben are buried beneath $5000 \mathrm{ft}$ or more of sediments. Similar interpretations result from the seismic studies (see Figure 12). Oil and gas wells show basin sediments to be 1000-3000 ft thick, but none of the wells for which logs have been obtained are drilled into the deepest parts of the graben (see Figure 8, especially concerning the well with a depth of $3000 \mathrm{ft}$, which lies just east of the Wendover Graben, and the one with a depth of $2350 \mathrm{ft}$ that lies just west of the Crater Island Graben). Although current information suggests that the thickest basin fill sediments may not be as great as that in some other geothermal areas (for instance, there is up to $8000 \mathrm{ft}$ of sediments in the basin hosting the Dixie Valley geothermal system), we will only know the greatest thickness of sediment after additional geophysical studies and deep drilling. But it is safe to say that a sediment thickness of $2 \mathrm{~km}$ is present in some of the deepest graben, and up to $3 \mathrm{~km}$ is certainly possible. Even in the absence of other heat-concentrating factors, such thicknesses in the GSLD, where heat flow is in the range of $100 \mathrm{~mW} / \mathrm{m}^{2}$, may be sufficient to sustain a system or systems capable of binary electrical power generation (see Figure 13).

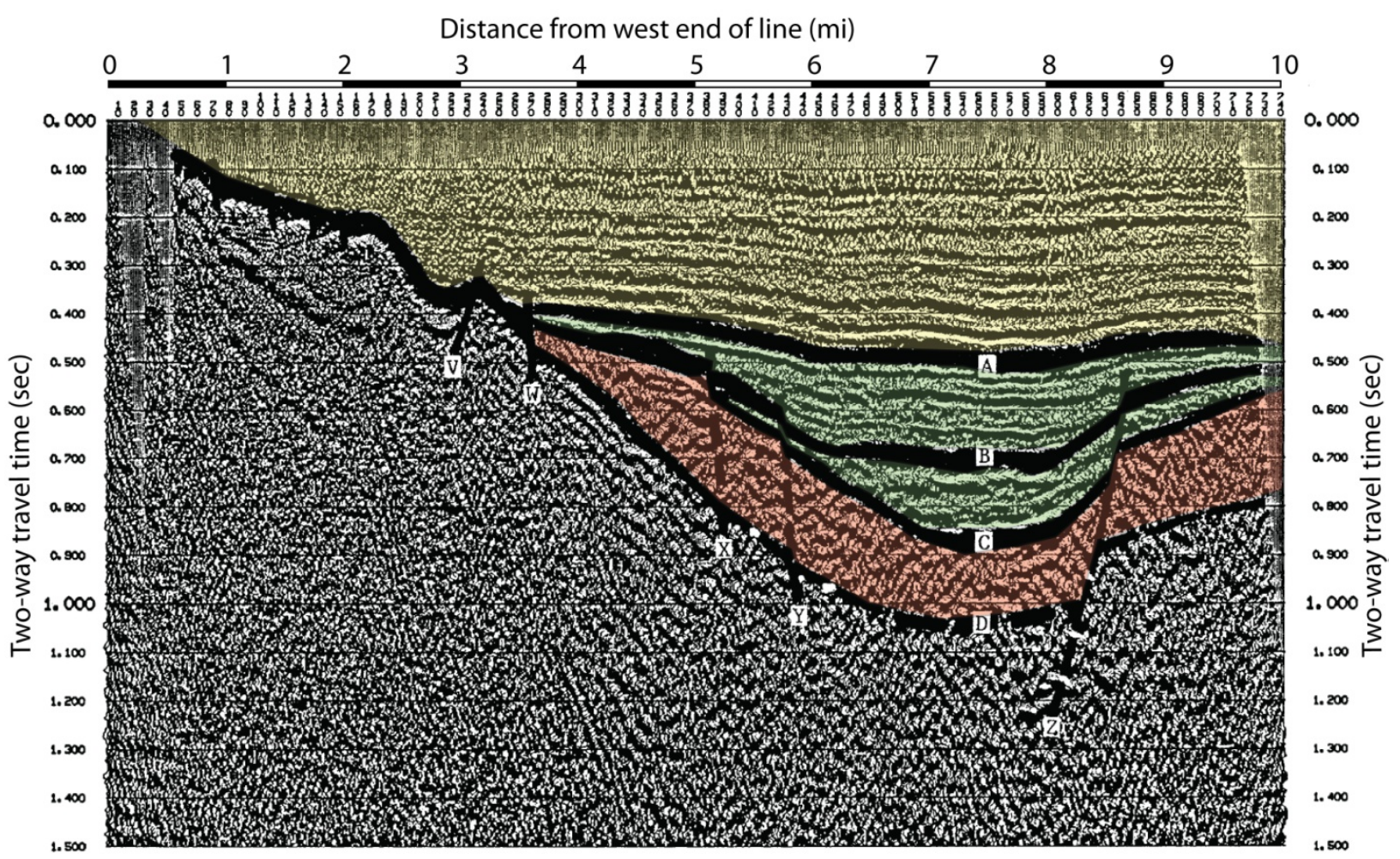

Figure 12. Seismic Reflection Section 3. Major reflectors are indicated by heavy black bands labeled A, $\mathrm{B}, \mathrm{C}$, and $\mathrm{D}$. The yellow shaded section above reflector "A" is interpreted to be unconsolidated sediments 1650 feet thick, The green shaded section between reflector " $A$ " and " $C$ " is interpreted to be consolidated Neogene sediments, mostly limestones and interbedded shales about 1450 feet thick. The red shaded section between reflectors "C" and " $\mathrm{D}$ " is interpreted to be volcanic rocks 1400 feet thick. The unshaded section below reflector " $D$ " is interpreted to be Paleozoic sediments. Graben-bounding faults are steeply dipping lines labeled V, W, X, Y, and Z. Modified from Kim (1985). 
Temperature (C)

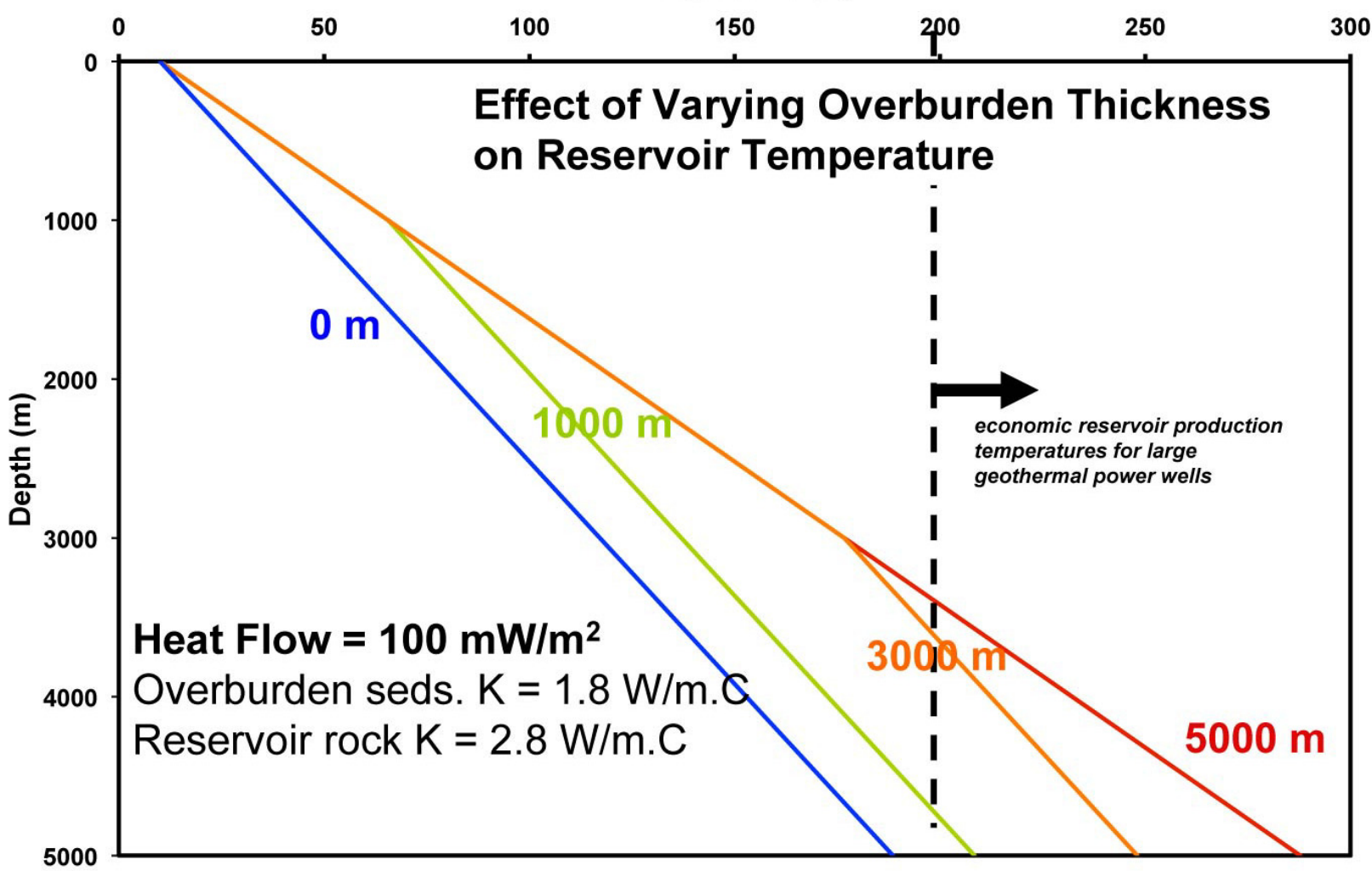

Figure 13. Effect of varying basin-fill thicknesses on potential reservoir temperatures. Note that for the assumed thermal conductivities (K) of basin-fill sediments (overburden) and bedrock (reservoir rock) the temperature at depth increases with increasing thickness of basin-fill sediments. For instance, with zero thickness (blue line) the temperature at a depth of $5 \mathrm{~km}$ is less than $200^{\circ} \mathrm{C}$, but for $1 \mathrm{~km}$ thickness (green line) the temperature would exceed $200^{\circ} \mathrm{C}$ at $5 \mathrm{~km}$, and for $3000 \mathrm{~m}$ thickness (orange line) the temperature would reach $200^{\circ} \mathrm{C}$ at a depth of only about $3.5 \mathrm{~km}$. For interpreted thicknesses of basin-fill sediment of 2000-3000 meters in parts of the GSLD, temperatures greater than $100^{\circ} \mathrm{C}$, capable of binary power production, may be expected at drilling depths of 2-3 km (Moore and Allis, 2011).

\section{Resurfacing of basin floor (Geothermal Exploration Model 3 applies)}

Playa areas of the basin and range province are periodically, often annually, flooded by runoff from surrounding mountains - runoff which carries sediments onto the playa floor. Any topographic expression of a tectonic event (i.e., a scarp produced by movement on a fault buried beneath the sediment) will therefore be quickly buried by younger sediments and/or modified by water flow. In the case of the GSLD, the resurfacing of the basin floor is also affected by periodic overflow of the Great Salt Lake during wet climatic cycles, and especially due to the pumping of the Great Salt Lake waters during the high-water crisis of the early and mid 1980's (Wold and Waddell, 1993; Jones et al., 2009). During such overflow events, surface topographic features of the playa floor are modified or eroded by water flow into the playa and buried by sediment carried in the water. Preliminary examination of aerial photographs (provided by Google Earth images) suggests that, despite these surface-modification processes, lineaments near some of the faults interpreted from gravity do exist. Such lineaments support the idea that these faults have moved so recently that some surface expression is preserved even in this active playa environment. 


\section{Thermal Springs (Geothermal Exploration Models 1 and 2 apply)}

It is evident that warm springs are present all around the GSLD. For example, the Blue Lakes Springs and others in the Bonneville Salt Flats on the west; Fish Springs and Wilson Health Spring near the south boundary of UTTR-S; Deseret Livestock Springs, Horseshoe Springs, Grandsville Warm Spring, and Big Warm Spring on the east; and Kimber Spring, Warm Spring \#2, and Locomotive Springs on the north. In addition, many wells in the GSLD area are classified as thermal wells (with a temperature of $>25^{\circ} \mathrm{C}$ ), some with thermal gradients of $45-100^{\circ} \mathrm{C} / \mathrm{km}$, and a few have gradients of $>100^{\circ} \mathrm{C} / \mathrm{km}$ (see Figure 2).

\section{Cold springs (Geothermal Exploration Model 3 applies)}

Cold springs (or non-thermal springs) are also common in and around the GSLD. They are not particularly useful at identification of areas of high geothermal gradient or heat flow, but they do sometimes provide information about fault locations and distribution. In many basins of the Basin and Range Province, springs form along buried fault zones, commonly in lines that define the fault trend. Typically, these springs are fed from permeable layers (i.e., sands, gravels) confined between impermeable layers (i.e., clays, silty clays) within the basin-fill sediments.

The sand and gravel layers (or aquifers) contain water that enters in or near adjacent mountain ranges and therefore is under hydraulic head. Faults that intersect the aquifers provide channelways for the water to move to the surface of the basin. Examples can be seen in many basins, including at Dixie Valley and Railroad Valley (see Figure 1), and help to define faults controlling basin structure. In the UTTR area, springs within the GSLD form in the same manner and help to define the locations of buried faults. For example, the curving line of springs along the west side of the Pilot Valley Graben (see Figure 8) coincides with the faults interpreted from gravity. Likewise, springs in the Wendover Graben, although not arranged in such a linear pattern, occur on and near interpreted faults and provide information directly relevant to one of our focus areas (see Figures 8 and 11). Areas of water outflow have been described in the area west of the Newfoundland Range; they are associated with mounds of algal mat buildup and cavernous openings beneath the surface (Jones et al., 2009). Such mounds commonly accompany intra-basin springs in Dixie Valley and other places in the Great Basin. In addition, Jones et al. (2009) report upward (positive) hydraulic gradients in shallow wells west of the Newfoundland Range.

\section{Quaternary Faults (Geothermal Exploration Model 3 applies)}

Many of the geothermal systems in the Basin and Range province can be shown to owe their existence to the circulation of water along Quaternary faults, some of which have sustained surface-rupturing earthquakes in historic time. The presence of Quaternary faults, some with strain rates of $>0.3 \mathrm{~mm} /$ year (see Figures 1,8 and 11), in and near the mountain ranges surrounding the GSLD suggest that extension rates are sufficient to maintain open channelways for geothermal water circulation. These faults are revealed by fault scarps cutting late Pleistocene alluvial fans, indicating major fault movements in the last few tens of thousands of years. The absence of such fault scarps within the GSLD itself should not be interpreted as an indication that no such youthful faulting exists there. This is because the sediments covering the GSLD are much younger than the alluvial fans adjacent to the ranges; in fact, they are young enough to cover surface evidence of any such Quaternary fault movement. Supporting this idea is the occurrence of Quaternary faults beneath the Great Salt Lake, recognized by offset of very young 
lake sediments in seismic reflection surveys (Denter and Pechmann, 1999; Hecker, 1993; Mikulich and Smith, 1974; Viverios, 1986; Currey, 1980; McCalpin, 1985; Robison, 1986).

\section{Contemporary seismicity (Geothermal Exploration Model 3 applies)}

Another way to gauge the activity level of faults in the current stress conditions is to monitor for seismic activity (or minor earthquakes) on faults. The Utah Seismic Stations at the University of Utah, the United States Geological Survey (USGS), and the Utah Geological Survey (UGS) have established earthquake monitoring networks throughout the state of Utah, and the earthquake locations recorded in historic time are plotted in Figure 8. The presence of numerous earthquake epicenters throughout the GSLD suggests that buried faults are active there; particularly encouraging is the proximity of some of the epicenters to faults interpreted from gravity information. Examples of this relationship include the several epicenters found near the Wendover Graben, the dense swarm of epicenters at the north end of the East Newfoundland Graben, and the diffuse band of epicenters extending northwest from the un-named graben in the east part of Dugway (see Figure 8). These all suggest fault activity that may be sufficient to maintain geothermal circulation within deeply penetrating faults.

\section{Source of water for geothermal systems}

The Great Basin hosted two large pluvial lake systems during the most recent glacial cycles (see Figure 14), one in the western part of the basin (specifically Lake Lahontan and the Lahontan Basin) and one in the eastern part of the basin (specifically Lake Bonneville and the Bonneville Basin). Many of the deep circulation geothermal systems in the Great Basin occur in or near these large pluvial basins. The water in the Dixie Valley and other geothermal systems of the Great Basin is Pleistocene in age, indicating that the systems were charged with water during the last glacial cycle, and that present hydrologic conditions have little input into the systems. The systems are in fact running on water introduced into the faults from pluvial lakes, and possibly local precipitation during the Pleistocene periods when the climate was much wetter than today's climate. During Holocene time, the water introduced during the last glacial cycle has circulated to depths sufficient to introduce observed heat (approximately $9 \mathrm{~km}$ depth at Dixie Valley) and ascended to fuel the current shallow systems. Because the UTTR area was covered by Lake Bonneville during the last glacial cycle (and probably previous cycles as well), it too has had ample opportunity for introduction into and deep circulation of large amounts of Pleistocene water through the fault systems underlying the GSLD. 


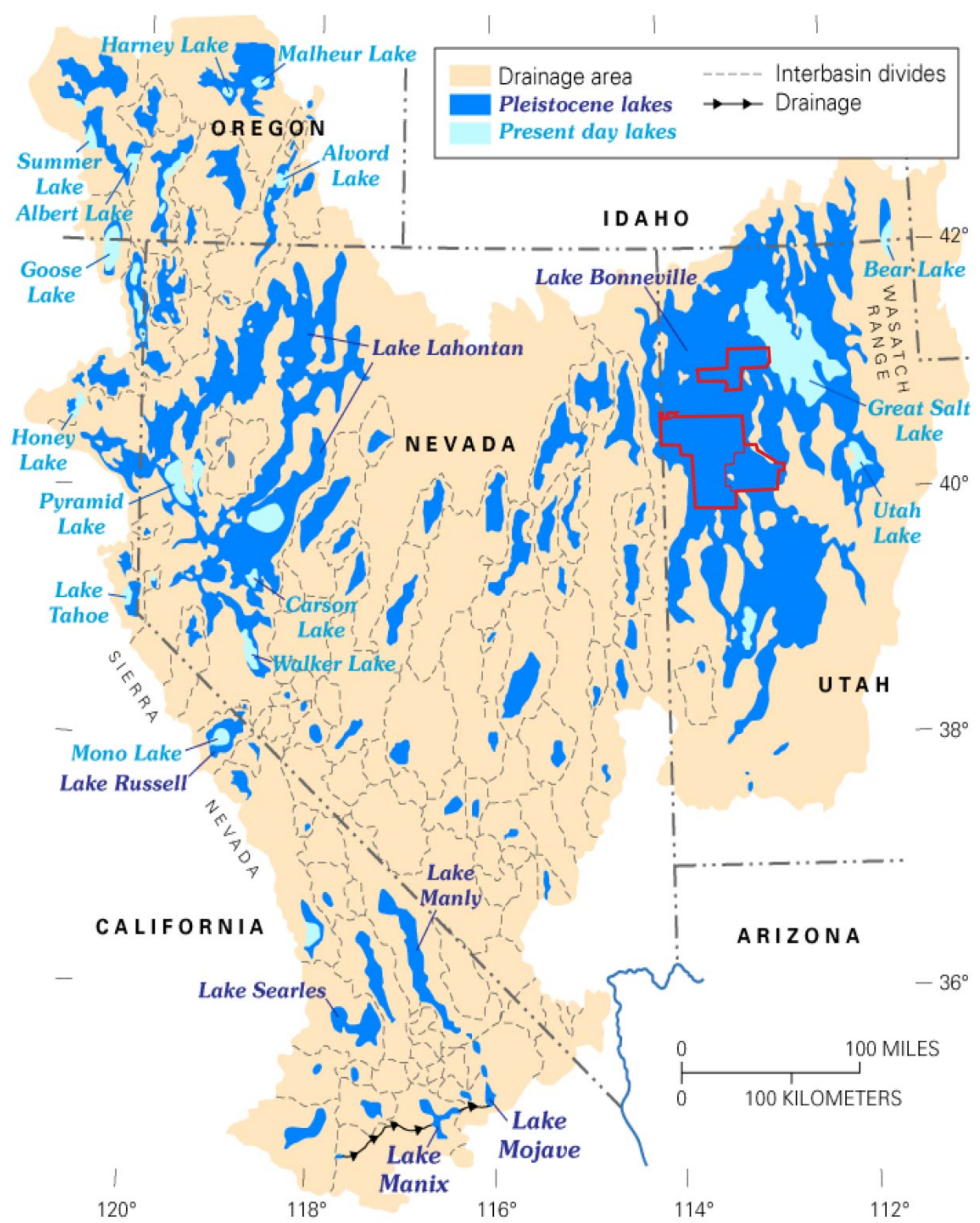

Figure 14. Map showing the extent of Pleistocene lakes in the Great Basin. UTTR/Dugway lands outlined in red (modified from Morrison, 1991). 


\section{Characteristics of rocks in adjacent and intra-basin mountain ranges (Geothermal Exploration Model 4 applies)}

Rock types present in the ranges adjacent to the GSLD include Precambrian metamorphic, igneous, and sedimentary rocks; Paleozoic sedimentary rocks; Mesozoic sedimentary rocks; Tertiary sedimentary, volcanic, and igneous intrusive rocks; and Quaternary sediments. Several of these rock types are known to have significant permeability. The Paleozoic and Mesozoic sedimentary rocks, which include thick sections of limestone and dolomite and thick sections of sandstone and quartzite, commonly have such high porosity and permeability that they serve as reservoir rocks for petroleum and gas. Because Paleozoic rocks have also been encountered in petroleum exploration wells beneath the basin-fill sediments, it is likely they will be present at depths appropriate for hosting geothermal reservoirs. In addition, the thrust-faulting, folding, and normal faulting to which most of these rocks has been subjected, commonly creates large areas of broken rocks with interconnected fractures. Because of the complex geologic history of the region, it will be difficult to predict the exact rock types present and the permeability conditions in exploration focus areas until deep exploratory drilling is performed.

\section{Lack of exploration due to military presence}

An underappreciated factor affecting exploration in the GSLD area is the exclusion from exploration activities of much of the land by the large military reservations. This factor contributes significantly to the lack of geologic knowledge of the area because little mapping of the surface geologic features and only limited geophysical surveys and drilling have occurred in recent decades. If parts of the military reservations are open to exploration activities for this project, then much of the uncertainty can be overcome.

\section{AREAS OF FOCUS ON UTTR/DUGWAY LANDS}

The available data for the GSLD, much of which is summarized in Figure 8, provides rationale for selection of promising geothermal exploration areas on UTTR/Dugway lands. It allows projection of favorable structures into UTTR/Dugway and comparison to analogous features in known geothermal systems. From a purely geologic point of view, there are four areas of the UTTR that at present hold the most promise for discovery of a geothermal resource (refer to Figure 8).

Focus Area 1: The western portion of UTTR-S - This area (Focus Area 1 on Figures 8 and 11) is of interest for several reasons. First, the Blue Lakes springs and other warm springs occur here. The Blue Lakes are fed by spring vents at the lake's bottom, and although the water temperature entering from the vents at this spot is not known, the lakes maintain a temperature of $84^{\circ} \mathrm{F}$ (Blackett and Wakefield, 2002). Also, the Wendover Graben and its associated bounding faults (as identified from existing gravity surveys of the area as shown in Figure 10) probably extends to the southwest from the area east of Wendover into the focus area. In fact, the warm springs at and near the Blue Lakes area may be localized by the southeastern graben-bounding fault. The southeastern side of the Wendover Graben has not been mapped into the Blue Lakes area yet, but an extrapolation of the gravity gradient shown in Figure 10 motivates collection of additional gravity data in the area this summer.

In addition, numerous springs in the area east and southeast of Wendover may also be localized by the graben-bounding faults. The oil wells southeast of Wendover and north of the 
focus area show that the thickness of sediment is about $3000 \mathrm{ft}$ east of the graben and greater than $3000 \mathrm{ft}$ within the graben. Gravity modeling indicates that the basin fill sediments in the deepest part of the graben is around $5000 \mathrm{ft}$ (Cook et al, 1965). They also interpret a complex system of two or more graben intersecting beneath the desert in the area south and southeast of Wendover (see Figure 11). Such intersections of graben and faults of different trends commonly produce extensive zones of fractured rock, which serve as pathways for the deep circulation of geothermal waters and for the development of near-surface geothermal reservoirs.

The presence of several earthquake epicenters east of Wendover suggest that the grabenbounding faults are still active, which is a condition necessary for maintaining open pathways for circulation of geothermal waters in the fault zones. In addition, several Quaternary faults mapped in the bedrock ranges northwest, north, and northeast of Wendover indicate contemporary tectonic activity in the area. Henrikson and Chapman (2002) show that heat flow calculated from an oil and gas well east of Wendover (specifically Alpha Minerals Federal \#1) and north of Focus Area 1 is $120 \mathrm{~mW} / \mathrm{m}^{2}$, which is among the highest heat flow values in Utah. Also, DB3, which is located about 5 miles southwest of Alpha Minerals Federal \#1 has a measured temperature of about $88^{\circ} \mathrm{C}$ at a depth of about 500 meters (Turk, 1973; Whelan and Petersen, 1974) (see Figure 11), suggesting a geothermal gradient of $176^{\circ} \mathrm{C} / \mathrm{km}$.

Focus Area 2: The western portion of UTTR-N - The western portion of UTTR-N (Focus Area 2 on Figures 8 and 11) is another area where multiple graben, and their bounding faults, converge in the subsurface. The Newfoundland Graben, the Crater Island Graben, and the Little Pigeon Graben are all inferred from gravity, and corroborated by seismic surveys. Seismic Reflection Line 3 (see Figures 8, 11, and 12) shows the positions and sense of movement on faults recognized in the seismic reflection surveys of Fitter (1985), Kim (1985), and Rene et al. (1988). In fact, Kim (1985) interprets 4500-5000 ft of Neogene-Recent sediments and volcanics in the deepest part of the Crater Island Graben, and faulting related to the west boundary of the Crater Island Graben is indentified in Line 2 (Rene et al., 1988).

The convergence of the three graben in and near Focus Area 2, and the potential intersection of these with NE-trending faults related to the Wendover graben, make this area particularly important. The intersecting faults may create a large broken zone in the bedrock for circulation of geothermal waters, and the great thickness of sediments above the basement rocks could prevent significant surface expression of a geothermal system here. The presence of numerous springs near the northern ends of the Little Pigeon, Crater Island, and Newfoundland graben, the occurrence of visible, north-trending lineaments on the surface, and the occurrence of several earthquake epicenters in the area all suggest that the faults are still active, and that they are therefore capable of maintaining open pathways for geothermal waters.

Focus Area 3: The central portion of UTTR-N - As the map in Figure 8 shows, Focus Areas 2 and 3 may in fact join, but for the sake of discussion they are separated here. Isostatic gravity indicates a deep graben east of the Newfoundland Range (i.e., the East Newfoundland Graben) and its interpreted boundary faults are shown in Figure 8. Several earthquake epicenters in the southern part of the graben and a large cluster of epicenters near the north boundary of UTTR-N suggest that this area is tectonically active and capable of maintaining a long-lived geothermal system. The area just south of the southern tip of the Newfoundland Range could also be the site of branching and intersecting faults. 
Focus Area 4: The eastern portion of UTTR-N - Focus Area 4, in easternmost UTTR-N, is in some ways the most promising area for the discovery of a potential geothermal resource. It is closely adjacent to the deepest graben in the area (beneath the Great Salt Lake) and gravity suggests that the western boundary fault of that graben crosses Focus Area 4 (see Figure 8). That boundary fault, even though it is located on the floor of the Great Salt Lake, has been identified as a Quaternary fault by seismic reflection sections (Currey, 1980; Hecker, 1993; Mikulich and Smith 1974). It is adjacent to the most seismically active area near the UTTR. Oil wells drilled into the graben beneath the Great Salt Lake have bottom-hole temperatures as high as $214^{\circ} \mathrm{C}$ and heat flow of over $100 \mathrm{~mW} / \mathrm{m}^{2}$. A deep exploration well drilled at the southeast corner of Focus Area 4 could intersect the bounding fault of a graben known to have very thick sediment fill, high temperatures within reasonable drilling depths, and high heat flow. Three oil wells just east of the focus area may provide significant information for well siting and may also allow the design of an exploration well to penetrate the fault at a depth where favorable rock types and high permeability would be expected. However, the logs of these wells are not publically available, but could probably be purchased from API. In addition, DOSECC drilled a series of core holes beneath the lake - two of them (Holes 4A and 4B, API number 4300330049) lie just east of the focus area. Also, several seismic reflection sections in the area show the locations of faults and major stratigraphic units in the graben-fill sediments.

\section{RECOMMENDATIONS FOR FUTURE WORK}

The 2011 project to assess the potential for geothermal development on UTTR/Dugway lands is a step towards addressing the nation's energy shortage. The information garnered in this assessment is extremely favorable and encouraging for the possibility of harvestable geothermal energy. However, the investigation has been hampered by a dearth of subsurface data. Of the several favorable areas identified in this report, Focus Area 1 has been selected for immediate additional exploration. In addition to its favorable geologic and geophysical characteristics, this is because of its close proximity to power transmission lines, capable of handling power from a geothermal plant.

Our results indicate that the best use of exploration funds will focus on collecting data to better characterize the nature and extent of the Wendover Graben, look for other evidence of geologic faulting, better characterize the permeability of the deeper geologic formations and to collect geochemistry data from wells and springs in the area to "finger print" waters for evidence of geothermal influences. The presence of the thermal water responsible for Blue Springs is an obvious target, however, the geologic structure responsible for charging the lake with warm water is not defined.

The planned investigations for the summer and fall of 2011 include a high resolution gravity survey, geochemical sampling of springs and wells, temperature logging of deep wells (as available), evaluation of surface lineaments that might indicate deep structures, and a detailed analysis of available geophysical well logs for oil exploration wells. This data will be used for identifying drilling targets with high potential for a geothermal discovery in Focus Area 1.

In the long-term, the other identified focus areas are also worthy of more detailed exploration, and the remainder of military land (UTTR-S and Dugway) should not be neglected. The entire GSLD has great potential for geothermal resources because of the high heat flow, the presence of Quaternary faulting, the great thickness of basin-fill sediments, and the proximity to 
many thermal springs and wells. No focus areas have been identified for much of the land under military control simply because of the lack of data. The eastern part of Dugway provides an illustration of the benefits of additional data collection throughout the area. Here, the close spacing of existing gravity stations enables interpretation of NW-trending graben-bounding faults, and a zone of earthquake epicenters extends northwestward, continuing the trend of the graben into the central part of UTTR-S (see Figure 8). Increased knowledge of the area in the central part of UTTR-S is likely to reveal areas of focus for detailed geothermal exploration activities. A long-term program of slow but steady data collection could lead to continued identification of areas suitable for further exploration and potential discovery. Such a program would need to spend only a few tens of thousands of dollars annually, and should be aimed at acquisition of data where little or none exists now. The major emphasis of this effort should include:

1. Acquisition of gravity data over large portions of UTTR-S and Dugway. The aim should be to cover the area with gravity stations to at least the station density of areas to the south of Dugway (see Figure 15).

2. Acquisition of high-resolution aeromagnetic data over as much of the area as possible. Resolution should be comparable to that of the 2010 USGS survey of northern Box Elder County.

3. Drilling and logging (i.e., temperature, lithology, geophysical) of a series of perhaps a dozen wells in areas of high potential to about $200 \mathrm{~m}$ depth to learn about variations in temperature gradient and heat flow values throughout the area.

4. Analysis of aerial photography and remote sensing imagery to identify any lineaments that may reveal locations and ages of movement of buried faults. 


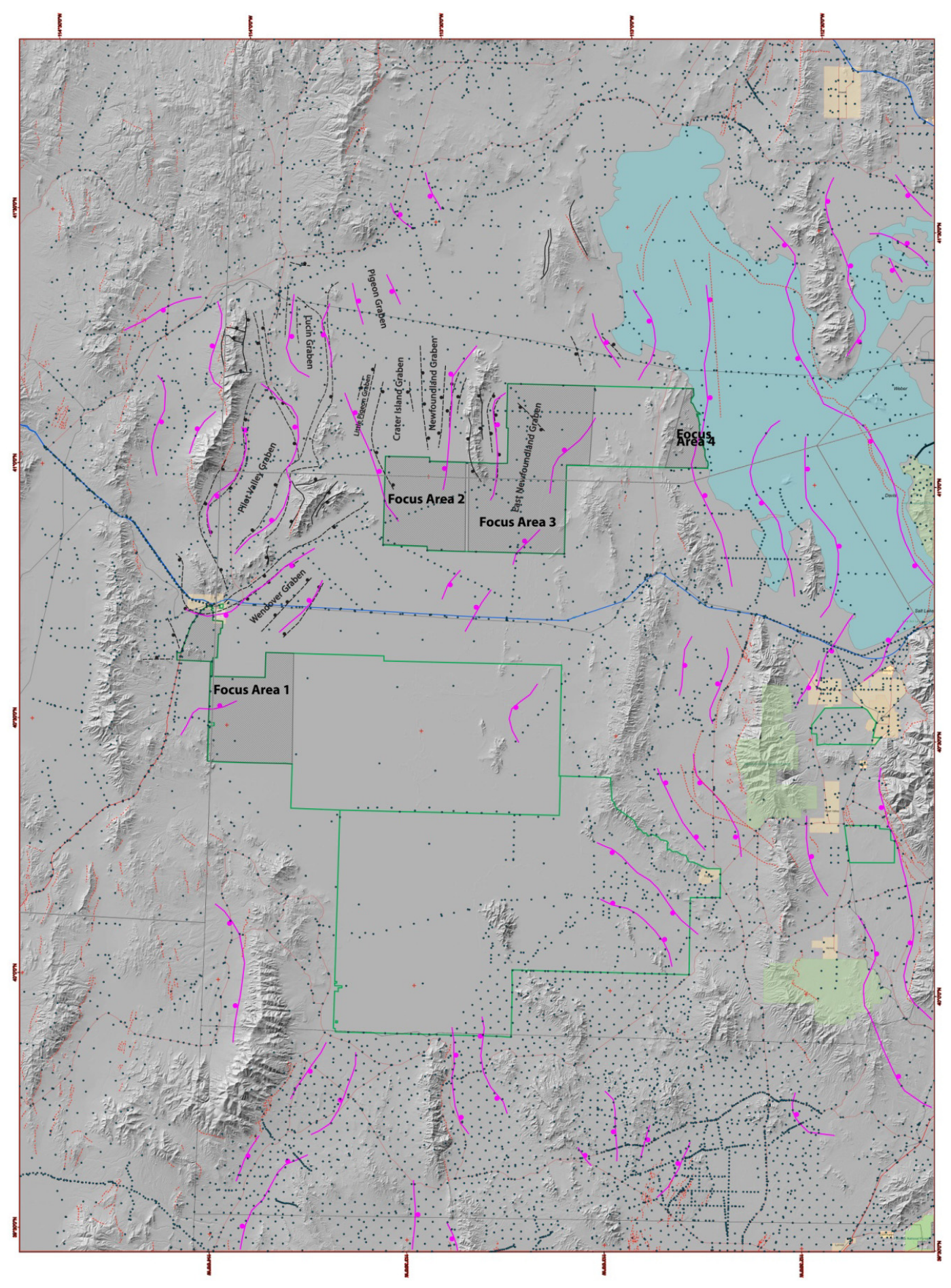

Figure 15. Map showing distribution of existing gravity stations (black dots) in and around the GSLD. UTTR/Dugway lands outlined in green. Cross-hatched areas are the focus areas identified based on geologic and geophysical information. Major roads in blue and red. Faults interpreted from gravity shown as dashed black lines and pink lines. Quaternary faults represented by dashed red lines. Note the sparsity of gravity stations south of Interstate 80 (blue line), including most of UTTR-S and Dugway Proving Grounds. The lack of gravity stations there precludes interpretation of subsurface structure. Gravity station locations from the Pan American Center for Earth and Environmental Sciences (PACES) website at University of Texas at El Paso: [http://irpsrvgis00.utep.edu/repositorywebsite/Default.aspx]. 


\section{REFERENCES}

Blackett, R. E., and S. I. Wakefield, 2002, Geothermal Resources of Utah: A Digital Atlas of Utah's Geothermal Resources, Utah Geological Survey.

Blackwell, D.D., 2007, "Summary of DOE Geoscience Studies of the Dixie Valley Geothermal System," Stanford University Geothermal Workshop, Stanford University, Stanford, California, January 30-February 1, 2007.

Cook, K. L., M. O. Halverson, J. C. Stepp, and J. W. Berg, Jr., 1964, "Regional Gravity Survey of the Northern Great Salt Lake Desert and Adjacent Areas in Utah, Nevada, and Idaho," Geol. Soc. Am. Bull., Vol. 75, pp. 715-740.

Currey, D. R., 1980, "Coastal Geomorphology of Great Salt Lake and Vicinity," in: Gwynn, J. W., ed., Great Salt Lake-A Scientific, Historical, and Economic Overview, Utah Geological and Mineral Survey Bulletin \#116, pp. 69-82.

Dinter, D. A., and J. C. Pechmann, 1999, "Multiple Holocene Earthquakes on the East Great Salt Lake Fault, Utah: Evidence from High-Resolution Seismic Reflection Data," Eos Trans. Am. Geophys. Union, Vol. 80, No. 46, Supplement p. F734.

Fitter, J. L., 1985, Seismic investigation near Silver Island in the Great Salt Lake Desert, Utah, M. S. Thesis, University of Oklahoma, Norman, Oklahoma, 75 pgs.

Hammond, W. C., and W. Thatcher, 2004, "Contemporary Tectonic Deformation of the Basin and Range Province, Western United States: 10 Years of Observation with the Global Positioning System," J. Geophys. Res., Vol. 109, pp. B08403-B08423.

Hecker, S., 1993, Quaternary Tectonics of Utah with Emphasis on Earthquake-hazard Characterization, Utah Geological Survey Bulletin \#127, 157 pgs., 6 pls., scale 1:500,000.

Henrikson, A., and D. S. Chapman, 2002, Terrestrial Heat Flow in Utah, University of Utah Department of Geology and Geophysics.

Jones, B. F., W. W. White, III, K. M. Conko, D. M. Webster, and J. F. Kohler, 2009, Mineralogy and fluid chemistry of surficial sediments in the Newfoundland Basin, Tooele and Box Elder Counties, Utah, Utah Geological Survey Open File Report \#539, 96 pgs.

Kim, K. Y., 1985, Seismic studies near Crater Island in the Great Salt Lake Desert, Utah, M. S. Thesis, University of Oklahoma, Norman, Oklahoma, 73 pgs.

McCalpin, J., 1985, Quaternary Fault History and Earthquake Potential of the Hansel Valley Area, North-Central Utah, USGS Final Technical Report, 37 pgs.

Moore, J., and R. Allis, 2011, "Novel Geothermal Development of Deep Sedimentary Systems in the United States," Proposal submitted to U.S. Department of Energy.

Morrison, R. B., 1991, "Quaternary Stratigraphic, Hydrologic, and Climatic History of the Great Basin, with Emphasis on Lake Lahontan, Bonneville, and Tecopa," in: Morrison, R. B., ed., Quaternary Nonglacial Geology: Conterminous United States, Vol. K2, Geological Society of America, Boulder, Colorado, pp.283-320 [http://esp.cr.usgs.gov/info/mojave/paleoenviron.html]. 
Mikulich, M. J., and R. B. Smith, 1974, Seismic-reflection and aeromagnetic surveys of the Great Salt Lake, Utah, Geological Society of America Bulletin, pp. 991-1002, 1 pl.

Rene, R. M., J. L. Fitter, D. J. Murray, and J. K. Walters, 1988, "Reflection and Refraction Seismic Studies in the Great Salt Lake Desert, Utah,” J. Geophys., Vol. 53, No. 4, pp. 431-443.

Robison, R. M., 1986, The Surficial Geology and Neotectonics of Hansel Valley, Box Elder County, Utah, unpublished M. S. Thesis, Utah State University, Logan, Utah, 120 pgs., scale $1: 24,000$.

Sass, J. H., A. H. Lachenbruch, R. J. Munroe, G. W. Greene, and T. H. Moses, Jr., 1971, “Heat flow in the Western United States," J. Geophys. Res., Vol. 76, pp. 6376-6413.

Sass, John H., Susan S. Priest, Arnold J. Blanton, Penelope C. Sackett, Stephanie L. Welch, and Mark A. Walters, 1999, Geothermal Industry Temperature Profiles from the Great Basin, USGS Open File Report \#99-425 [http://pubs.usgs.gov/of/1999/of99-425/].

Turk, L. J., 1973, Hydrogeology of the Bonneville Salt Flats, Utah Geological and Mineral Survey Water Resources Bulletin \#19, 81 pgs., 1 pt.

Utah Geothermal Working Group, 2005, Geothermal Energy Development in Utah, Position paper.

Viveiros, J. J., 1986, Cenozoic tectonics of Great Salt Lake from seismic-reflection data, unpublished M. S. Thesis, University of Utah, Salt Lake City, Utah, 81 pgs.

Whelan, J. A. and C. A. Petersen, 1974, "Bonneville Salt Flats_-A Possible Geothermal Area?," Utah Geology, Vol. 1, No. 1, pp. 71-82.

Wold, S. R., and K. M. Waddell, 1993, Salt Budget for West Pond, Utah, April 1987 to June 1989, USGS Water Resources Investigations Report \#93-4028, 20 pgs. 